From Deconstruction to the Possibilities of Radical Alternatives: Anarchy within the Matrix of Domination

by

\title{
Mariful Alam
}

A thesis submitted to the Faculty of Graduate and Postdoctoral Affairs in partial fulfillment of the requirements for the degree of

Master of Arts

in

Legal Studies

Carleton University

Ottawa, Ontario

(C) 2012, Mariful Alam 
Library and Archives

Canada

Published Heritage

Branch

395 Wellington Street

Ottawa ON K1A ON4

Canada
Bibliothèque et

Archives Canada

Direction du

Patrimoine de l'édition

395 , rue Wellington

Ottawa ON K1A ON4

Canada
Your file Votre référence

ISBN: 978-0-494-94281-9

Our file Notre référence

ISBN: 978-0-494-94281-9
NOTICE:

The author has granted a nonexclusive license allowing Library and Archives Canada to reproduce, publish, archive, preserve, conserve, communicate to the public by telecommunication or on the Internet, loan, distrbute and sell theses worldwide, for commercial or noncommercial purposes, in microform, paper, electronic and/or any other formats.

The author retains copyright ownership and moral rights in this thesis. Neither the thesis nor substantial extracts from it may be printed or otherwise reproduced without the author's permission.
AVIS:

L'auteur a accordé une licence non exclusive permettant à la Bibliothèque et Archives Canada de reproduire, publier, archiver, sauvegarder, conserver, transmettre au public par télécommunication ou par l'Internet, prêter, distribuer et vendre des thèses partout dans le monde, à des fins commerciales ou autres, sur support microforme, papier, électronique et/ou autres formats.

L'auteur conserve la propriété du droit d'auteur et des droits moraux qui protege cette thèse. $\mathrm{Ni}$ la thèse ni des extraits substantiels de celle-ci ne doivent être imprimés ou autrement reproduits sans son autorisation.
In compliance with the Canadian Privacy Act some supporting forms may have been removed from this thesis.

While these forms may be included in the document page count, their removal does not represent any loss of content from the thesis.
Conformément à la loi canadienne sur la protection de la vie privée, quelques formulaires secondaires ont été enlevés de cette thèse.

Bien que ces formulaires aient inclus dans la pagination, il n'y aura aucun contenu manquant. 


\begin{abstract}
This thesis critically explores contemporary anarchistic politics. In particular, it examines the relationship between anarchist theory and social transformation to see how it can offer scholars a new way to look at possibilities of anti-authoritarian alternatives to both the existing neo-liberal order, and to the failed State-communist programs of the Twentieth century. What distinguishes the anarchist milieu is its emphasis on employing anti-hierarchical forms of social interaction within the methods of organization. This practice manifests the very forms of social relationships that activists hope to achieve in the longer term. In other words, anarchists are committed to the ethos of prefigurative politics, which seeks to collapse the distinction between their means and ends. Thus, by closely exploring these prefigurative practices-spokescouncils, consensus decisionmaking, and black bloc formations-it reveals and opens the doors to post-utopian possibilities of resistance and alternative ways of being, although they remain imperfect and seemingly paradoxical.
\end{abstract}




\section{Acknowledgements}

First and foremost, I would like to thank my supervisor, Professor Nicolas Carrier, for his patience, guidance and support. I also would not have been able to complete this project without the emotional support and assistance from my dearest friends Amelia Edwards, Matthew McManus, Agnes Barr-Klouman, and Morgan Meloche. And finally, I would like to thank my family for being there for me during every step of this tedious process. 


\section{Table of Contents}



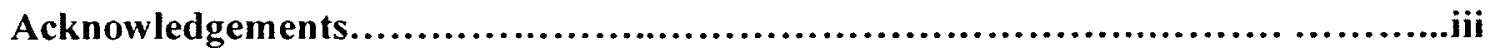

Table of Contents......................................................................

Introduction: The Wavering Radiant.........................................4

Chapter One: Breaking the Spell..................................................................11

1.1 Classical Anarchism .................................................

2.2 The Emergence of a Post-Utopian Anarchism...........................28

Chapter Two: To Here Knows When: On Possibilities and Imagination..............52

2.1 Macro-Organization................................................. 54

2.2 Micro-Organization.............................................. 67

Chapter Three: Behind the Black Mask..........................................82

3.1 (Social) Insurrection \& Post-Utopian Resistance..........................84

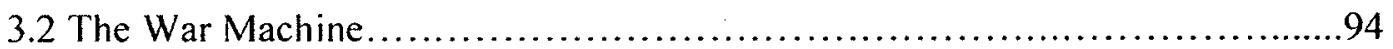

3.3 Theatre Machines..................................................... 100

Conclusion: An Endless Transmission........................................108

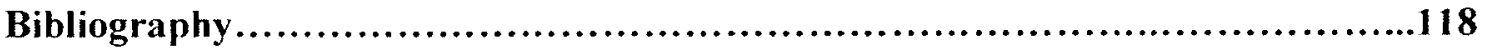




\section{INTRODUCTION THE WAVERING RADIANT}

"Paradox: to embrace Chaos is not to slide toward entropy but to emerge into an energy like stars, a pattern of instantaneous grace - a spontaneous organic order completely different from the carrion pyramids of sultans, muftis, cadis \& grinning executioners."

- Hakim Bey

1 rom the Battle of Seattle to the ongoing anti-austerity riots in Greece, the last scale that has been largely unseen since World War II. For most people, the terms 'anarchy' and 'anarchism' continues to evoke negative images of senseless violence, chaos, and destruction by young masked-nihilists hell-bent on throwing petrol bombs and destroying private property. And indeed it is true that some activists do partake in such violent actions. However, the anarchist milieu is largely misunderstood, while its influence on a variety of social movements throughout the twentieth century remains underappreciated.' The aim of my project is to critically explore contemporary anarchistic politics. ${ }^{2}$ In particular, I examine the relationship between anarchist theory and social transformation in order to see how it can offer social scientists a new way to look at possibilities of anti-authoritarian alternatives to both the existing neo-liberal hegemonic order, and to the failed State-communist programs of the Twentieth century.

When I first began my research, I asked: What exactly is anarchism? What do anarchists perceive as domination? What are the possibilities of emancipation and

\footnotetext{
1 These movements include, but are not limited to organized labour, feminist, LGBT, squatters, antinuclear, 1960's student strikes, anti-globalization, environmental, animal liberation, occupy, among others. A detailed analysis on anarchism's influence on new social movements can be found in Uri Gordon's Anarchy Alive! (2008).

${ }^{2}$ All subsequent references to contemporary anarchists are in reference to activists from the so-called Global North (North America, Western Europe, Australia, and New Zealand).
} 
resistance? How do anarchists envision social organization? And what are the possibilities of living in an anarchic society? After starting my thesis, however, I realized that answering these questions was a difficult and daunting task, for there were no singular answers. Not only are there multiple traditions of anarchism-syndicalism, feminism, primitivism, communism, collectivism, and so on -but many activists, as Heather Gautney rightly points out, tend to eschews the very idea of formulating a general, all-encompassing idea of social change (see Gautney 2012).

Despite their differences, one can perhaps contend that those who identify with the anarchist milieu, no matter what tradition, seek to dismantle all forms of social, political, and economic hierarchies and domination. Historically, anarchists perceived these systems of domination - be it patriarchy, white supremacy, heteronormative hegemony, or capitalism - as gravitating from the centralized State. The objective for anarchists, then, was to directly abolish the State and its apparatuses, with the hopes of replacing them with a horizontal-network of autonomous, voluntary associations based on the principles of direct democracy, solidarity, and mutual aid. Such a project, it was believed, would allow subjects to be emancipated from the constraints of power, authority, and social control, allowing the liberated individual to freely explore alternative ways of being.

While today's anarchists continue to organize around the basic tenets noted above, their epistemology differs sharply from those of the past. Anarchists no longer locate their struggle against a singular, archaic power from which domination emanates. Rather, power is perceived to be fluid, occurring form a multiple points and institutions, and therefore compelling anarchists to (re)-strategize their tactics against domination. 
Anarchists also do not anticipate a coming revolution. Their modes of organization are not working towards a hegemonic social transformation, but rather, as a present-tense experimentation, as anarchy yet-to-come. Giorel Curran summarizes this in her theory of 'post-ideological' anarchism:

[T] he anarchism that [the forces of globalization have] unleashed is a considerably reconfigured one. The term post-ideological anarchism is used to describe it. Post-ideological anarchism informs the impulse, culture and organisation of oppositional politics today. It refers to the looser and more flexible embrace of anarchist ideas and strategies in the armoury of radical dissent. Post-ideological anarchists are inspired by anarchism's principles and ideas, drawing from them freely and openly to construct their own autonomous politics. They reject doctrinaire positions and sectarian politics, preferring to mix their anarchism with an eclectic assortment of other political ideas and traditions" (Curran, 2006: 2).

This signals an emergence of a new kind of anarchism, a post-utopian anarchism, which has begun to strip its essentializing and humanist elements. This focus has also signified a shift from the search for a coherent ideology or identity to an emphasis on developing a method of practicing politics. Given this (re)-conceptualization, I also explore and answer how anarchists attempt to transcend hegemonic and essentialist politics.

To answer the questions posed above, I do not simply explore abstract theoretical arguments, but also examine contemporary anarchistic practices. Perhaps what uniquely distinguishes the anarchist milieu is its emphasis on employing anti-hierarchical forms of social interaction within their own methods of organization. This practice manifests the very forms of social relationships, albeit in a miniature form, that activists hope to achieve in the longer term (Franks, 2010:145). In other words, anarchists are committed to the ethos of prefigurative politics, which seeks to collapse the distinction between their means and ends. My task, therefore, is to closely explore these prefigurative practices 
because I believe it reveals new post-utopian possibilities and alternative ways of being, although, as we shall in the subsequent chapters, they remain imperfect and seemingly paradoxical.

In chapter one, I map the continuity and changes between "classical" and "contemporary" anarchism by drawing on a wide range of literature. My contention is that while anarchism initially began as a utopian project, the movement(s) has begun deconstructing its essentialist and humanist foundation, paralleling the critiques put forth by poststructuralist thinkers such as Michel Foucault and Jacques Derrida. This highlights the (re)-emergence of an anarchism which revolves around a politics of becoming and a revolution yet-lo-come. To accurately capture this shift, I begin with a discussion of two classical thinkers who have set the foundation for the anarchist milieu: Peter Kropotkin and Mikhail Bakunin. ${ }^{3}$

While offering a vigorous critique of liberal-democracy, and unmasking the authoritarian currents of orthodox Marxism, today's anarchists consider the classical fusion of theory/praxis as incapable of immanently attaining liberation. In the second part of chapter one, I illustrate how contemporary anarchists have utilized Foucault's work to unmask Kropotkin and Bakunin's misguided understanding of power, human nature, and subjectivity. What I hope to show is that this misunderstanding is not only believed to be limiting, but also hegemonic and therefore dangerous. To transcend these limitations, and to escape the trap of hegemonic politics, I sketch how contemporary anarchists have begun to invoke Derrida:s deconstructive practice, opening the doors to the possibilities of a post-utopian anarchy and resistance.

\footnotetext{
${ }^{3}$ Admittedly, limiting my analysis oversimplifies the diverse history and tradition of "classical" anarchism. A more extensive history can be found in Peter Marshall's Demanding The Impossible (1992).
} 
In the second chapter, I explore, analyze, and critique contemporary anarchist prefiguration. My argument is that the practices found within the anarchist networks, communes, and groups offer alternative visions to the existing hegemonic order. To demonstrate this, the chapter is divided into two parts. The first part illustrates how anarchists organize around spokescouncil assemblies, which is not only a tool for organizing direct actions, but its informal 'infrastructure' also offers a vision for 'macro' social organization.

The second part of chapter two investigates how anarchists organize around the affinity group model, which not only prefigures a possible vision for organizing a small community or neighbourhood, but its emphasis on consensus decision-making also indicates an attempt by anarchists to develop a 'micro' decision-making practice that can transcend law's violence as conceived in the Derridean sense. Although both spokescouncils and consensus decision-making in their current form continue to be limited by their paradoxical norms and procedural contradictions, they nonetheless reveal that alternative possibilities to the law and the State-form can be imagined through continuous struggle and experimentation.

In the third and final chapter I explore anarchic resistance. For most anarchists, the State is a self-protecting entity that must be constantly warded off through a diversity of tactics, including confrontational ones. The latter is most clearly encapsulated by the "violent" actions of a "group" known as the black bloc. This group is not a formal political organization, but rather an ad-hoc tactical formation of affinity groups and individuals that cluster together during large protests to attack symbols of the State and capitalism. My contention is that black bloc formations illustrate an emergence of a new, 
prefigurative politics of insurrectionary resistance that attempts to transcend the limitations of counter-hegemonic practices and essentialism.

I begin the chapter with a discussion on the theoretical origins of black blocs. Rather than calling for a militarized revolution, black bloc activists call for a social insurgency which deliberately avoids the physical assault of human bodies. Here I demonstrate that black bloc activists are not only influenced by Foucault's work on power, subjectivity, and his notion of social war, but also other thinkers such as Giles Deleuze, Felix Guattari, and Guy Debord. These thinkers help fill gaps in Foucault's work.

The second section of chapter three explores the relationship between emancipation and political violence. In contrast to the traditional understanding of revolutionary violence, I contend that the black bloc tactics attempt to subvert existing systems of domination, allowing the subject to be temporary emancipated, and therefore, allowing them to prefiguratively explore alternative ways of being. To demonstrate this argument, I provide an analysis of and comparison between Frantz Fanon's notion of decolonial violence, and black bloc tactics of sabotaging private property.

Finally, in the third section of chapter three, I explore the relationship between black bloc aesthetics and the (re)-production of subjectivity and identity. By drawing upon Deleuze and Guattari's theory of face and subjectification, I illustrate how a black uniform - black masks, black clothes, black shoes-allows subjects to prefiguratively experiment with new anti-capitalist and anti-authoritarian identities as yet-to-come, signaling a desire to transcend identity politics. However, it does not escape the trap of 
essentialist subjectification, which in turn has allowed the State to repress anarchic dissent. 


\section{CHAPTER 1 \\ BREAKING THE SPELL}

\footnotetext{
"The state? What is that? Now open your ears for now I shall speak to you of the death of peoples. The state is the coldest of all cold monsters. Coldly it lies, too; and this lie creeps from its mouth: 'I, the state, am the people."'

-Friedrich Nietzsche
}

Anarchism is a diverse anti-authoritarian 'movement of movements' that consists of a variety of groups, collectives, and individuals that not only share a set of ethical commitments to resist the matrix of domination, but also a commitment to organize around prefigurative politics - the idea that what is desired must also be involved in the methods of reaching that aim. My overall contention is that anarchist prefigurative politics reveals the possibilities of post-utopian alternatives to existing institutions such as the State and judicial system, albeit in a miniature and imperfect form. However, before I provide an analysis of anarchist prefigurative politics, I will first explore its theoretical foundation. 1 shall present a brief survey of anarchist theory by discussing the continuity and changes between "classical" and "modern" anarchist literature. This exploration will be guided by four questions: What is anarchism? What is power and domination? How can one organize? What are the possibilities for resistance and social transformations?

I begin the chapter with an analysis of classical anarchist literature. Here, my aim is not to provide a thorough analysis of every anarchistic tradition, but rather to track and identify key themes that have shaped and contributed to contemporary anarchistic thought. In doing so, I explore the works of two highly influential thinkers: Mikhail Bakunin and Peter Kropotkin. My aim is not only to examine the key elements of their 
political philosophy that remains considerably important within anarchist literature, but also explore those aspects that today's anarchists have come to problematize.

In the second half of the chapter, I analyze how contemporary anarchists have deconstructed the ontological assumptions of classical anarchism in light of poststructuralist critiques. More specifically, I explore the works of Michel Foucault and Jacques Derrida, and investigate how their theories have both challenged and contributed to anarchistic thought. My goal is to demonstrate how the trend within contemporary anarchist literature has begun rejecting certain essentializing traits and programmatic conclusions to strengthen the anarchist project - although sometimes in a paradoxical manner. This trend, I believe, highlights the emergence of a new kind of anarchism -a post-utopian anarchism.

\section{1. "CLASSICAL" ANARCHISM}

\subsection{LAW \& AUTHORITY}

\section{The Social Contract}

Nineteenth-century anarchists such as Kropotkin and Bakunin argued that the philosophical justification for the modern State could be traced to Thomas Hobbes' Leviathan. Hobbes asserted that a sovereign should be authorized through a social contract to take whatever action is necessary to maintain social order, even if this means regulating human conduct through monopolized violence. Hobbes" social contract relied on a combative presumption about human nature, which portrayed humans as inherently selfish, aggressive, competitive beings and, when in a state of nature, permanently engaged in a war of 'every man, against every man' (See Hobbes, 1991). To end this 
permanent state of war, Hobbes suggested that individuals should formulate a social contract and establish a civil society upon which a form of authority could be developed. He believed people should sacrifice part of their freedom in order to pursue their own ends in a more peaceful manner. Thus, individuals within civil society are expected to agree with and reinforce the creation of a sovereign State that can "arbitrate between conflicting wills and enforce a state of peace and order" (Newman, 2001: 43).

Classical anarchists, however, rejected the premise that individuals had to sacrifice a part of their freedom to establish order. Anarchists argued that the social contract served to conceal the violence of the State. Bakunin, for example, exposed the social contract as "an unworthy hoax"; he exposed it as an ideological fiction created to legitimize existent relationships of domination (Bakunin, 1984: 136). For Bakunin, there was a paradox in the social contract: if, in a state of nature, people lived in primitive savagery, how can they suddenly have the imagination to create a social contract with one another? If there are no common bonds, if no essence brings people together, then on what basis can a social contract be formed? Bakunin refused to be "deceived by social contract theorists, those apologists for the state like Hobbes and Locke, who saw sovereignty as being founded on rational consent and the desire to escape the state of nature" (Newman, 2007: 6). The social contract was perceived as a mask for the real illegitimacy of the state; the fact that sovereignty was violently imposed on people, rather than emerging through "rational" consent (Newman 2007: 6). 


\section{Natural Law \& Social Solidarity}

Bakunin argued that the only acceptable forms of "authority" were the first two human laws: social solidarity — cooperation between individuals - and liberty - the desire for freedom and creativity. According to Bakunin, it is impossible to escape these "natural" laws because "they envelop us, penetrate us, regulate all our movements, thoughts and acts" (Bakunin, 1970: 20). Where liberal political theorists saw cooperation and liberty as a consequence of government, Bakunin perceived these concepts as a natural product of society. He argued that it was society, not a legislator that determined what liberty was and how one could attain it. Furthermore, unlike State law, natural laws did not "humiliate, dominate, and enslave" individuals through fear, monopolized coercion, and private property rights. Whereas State law required an external master and legislator, natural laws did not require a sovereign power; they were the basic and fundamental conditions of human existence. Recognizing the natural laws of solidarity and liberty was thus the most crucial step in unmasking the illegitimacy of the State and of domination. As Bakunin wrote,

"I am truly free only when all human beings, men and women, are equally free. The freedom of other men, far from negating or limiting my freedom, is, on the contrary, its necessary premise and confirmation. It is the slavery of other men that sets up a barrier to my freedom...For my dignity... is reflected by the equally free conscience of all and confirmed by the consent of all humanity" (1971: 327).

Bakunin's concept of liberty also had a close connection with another ideal equality. For Bakunin, freedom had no meaning except within the context of equality. He affirmed, "the freedom of each may only be achieved through the equality of all," and that "the realization of freedom through equality, in principle and in fact, is justice" (1971: 79). Moreover, Bakunin asserted that there was a universal moral impulse towards 
equality. He argued "the institutional passion of the masses for economic equality is so great that if they could hope to receive it from the hands of despotism, they would indubitably and without much reflection do as they have done before..." (1950). Thus, Bakunin's idea of a peaceful social order was one where every man and woman would find an equal opportunity to make use of his or her abilities without interference from the State and or private property rights (Pyziur, 1968: 117-118).

\section{Mutual Aid \& Popular Law}

Similar to Bakunin's theory, Kropotkin argued that positive law was man-made, artificial, and was used by the State as an instrument of political domination. His attack on law was twofold: that it had been violently imposed by the ruling classes, and that it was unnecessary. Whereas early human relations were simply regulated by "customs, habits, and usages made sacred by constant repetition," Kropotkin asserted that State laws confirmed and crystallized social customs, "but while doing so, took advantage of establishing, in a disguised form, the germs of slavery and class distinction." The origin of State law was perceived by Kropotkin as the "desire of the ruling class to give permanence to customs they had imposed for their own advantage" "customs only useful to rulers, injurious to the mass of the people, maintained only by the fear and threat of punishment' (Kropotkin, 1968:174-215). In a capitalist society, these customs maintained the ownership of private property in the hands of a few individuals, which, in turn, produced an unjust social order that was based on inequalities, hierarchies, and exploitation. Therefore, Kropotkin perceived the judicial field as an extension of the 
State. In a capitalist society, it was an institution used by the Bourgeoisie to maintain domination over the masses.

In contrast to what he called "artificial law", Kropotkin argued that early humans developed their ethics and morality by observing the processes of nature. ${ }^{4}$ This he termed "natural", or "popular" law. Unlike State law, Kropotkin asserted that popular law omitted what was considered to be paradigmatic: that which was defined, written down, and procedurally enforced by an external authority (Clark, 2007: 88). Popular law, on the other hand, was inseparable from morality in itself which was characterized by sociality, a prohibition against killing one's own kind, and reciprocity in responding to wrongful acts. Popular law was considered "common" sense and was visualized as a tool to ensure peace between members of a community, to settle any disputes that may arise, and to help one another (Kropotkin, 1968: 41). For Kropotkin, therefore, human nature tended toward social solidarity, or what Kropotkin called mutual aid - cooperation amongst one another-and not competition or violence.

In Kropotkin's analysis, appealing to a sense of humanity within the individual could abolish behaviors that society considered to be "social harms." Crime was a social construct, he argued, not a natural condition. Social harms should be treated not as an evil, but as a disease that could be cured through moral hygiene. Society had no need for the state; it had its own regulating mechanisms and its own natural laws. Kropotkin argued that by returning to popular laws, society would limit the probability of social harms and also render unnecessary the use of "inhumane" apparatuses such as the police, criminal courts, and prisons. In his opinion, anti-social behaviour should be "nipped in

\footnotetext{
${ }^{4}$ Kropotkin regarded early humans as hunter-gather and rural agricultural (or peasant) societies. He also referred to both as organic communities.
} 
the bud" but not punished. In a post-revolutionary society, any social harm that could arise could be "easily settled by arbitrators; and no more force would be necessary to impose their decisions" (Kropotkin, 1968: 73)

At the core of classical anarchist theory were assumptions about human nature and essence. Classical anarchists believed that communities that existed outside the realm of artificial power were "rationally" ordered, in the sense that the subjects inherently possessed certain characteristics, which, once realized, would allow them to live relatively peacefully with one another. Artificial power was conceived as corrupting this rationally ordered society by alienating the human essence through the production of an inegalitarian and miserable social order. In a capitalist society, this undesirable social order was seen to be a result of the private ownership of the means of production, and exploitation of the workers, which the state maintained through fear and punishment.

\subsection{THE STATE}

A close reading of Kropotkin and Bakunin's writing reveals that anarchists concurred with Karl Marx insofar as they agreed that the State protected and reproduced capitalist social relations. ' Classical anarchists also agreed with Marx's earlier writings, where he argued that man had not realized the full potential of his development and selfrealization: the human essence was alienated in the capitalist system and would, therefore, be liberated. Where the two philosophies differed, however, were in their

\footnotetext{
${ }^{5}$ David Graeber writes that anarchists have long formulated their theories on political economy from Marx. For example, while Bakunin was a political rival of Marx, Bakunin was also responsible for the first translation of Das Kapital into Russian (Graeber, 2009: 211 ).
} 
characterizations of the state and the methods of social organization needed resist against domination.

\section{Marxism \& The Revolutionary Vanguard}

Marx believed that the State would inadvertently create social conditions that would ultimately be used by the proletariat class for revolutionary ends. The state was seen as a product of social forces; especially the economic power of the bourgeois class. Liberal-states were seen as being derived from the "primary evil" of bourgeois economic exploitation and private property. While Marx agreed with anarchists that the State was an oppressive entity that would eventually be overcome, he believed that revolutionary strategy for social change meant that temporarily controlling the State was imperative before the state could "wither away" (Newman, 2010: 262). The State was perceived as a capitalist institution and, during the transition to communism, when "class distinctions disappeared, and the means of production had been concentrated in the hands of a vast association of the whole nation, public power will lose its political character" (Marx \& Engels, 1978: 490). Marx therefore argued that after a proletarian revolution, both the State and the judicial field could be used as a site for embedding a communist program to diffuse capitalist power.

By contrast, anarchists viewed the State and all forms of political power as irredeemable mechanisms of oppression. Anarchists argued that the law could not simply be reduced to a tool to be employed for bourgeois purposes; they believed that it was used by the State, which is a priori a mechanism of domination no matter what historical 
form it takes. For example, in a debate with Marx during the First International, Bakunin argued:

"[Marx] holds that the political condition of each country is always the product and the faithful expression of its economic situation... He takes no account of other factors in history, such as the ever present reaction of political, juridical, and religious institutions on the economic situation. He says: 'Poverty produces political slavery, the State.' But he does not allow this expression to be turned around, to say: 'Political slavery, the State, reproduces in its turn, and maintains poverty as a condition for its own existence; so that to destroy poverty, it is necessary to destroy the State!" (Bakunin, 1971: 281-282).

In other words, for Bakunin oppression was not merely an expression of class power but inherent within the structure of the state itself. He believed that the state ruled through the dominant class, "in the sense that bourgeois relations are a reflection of the State" (Newman, 2001: 2).

Bakunin also warned that the bourgeoisie was only one of the state's manifestations. If the bourgeoisie were destroyed, the state would create another class in its place through which it would perpetuate its power, even in an allegedly classless society (Bakunin, 1984: 41). This is why, in a post-revolutionary society, anarchists viewed capturing the State as a terminally flawed strategy. Rather than "withering away" as Marx had proposed the State would do, anarchists argued that it would, instead, become entrenched under Communism and generate 'new forms of power structures." According to Bakunin, Marx's vision of the State under communism would translate into a "despotic machine controlled by a new technocratic class that would exercise possibly an even greater degree of power over society than under the bourgeoisie" (Bakunin cited in Newman, 2010: 262).

Thus, one of the central themes of classical anarchism was the rejection of 
government and political representation. Power was perceived as being centralized within the hands of a ruling minority who created rules through legislative bodies under the illusion of representation. Formal courts, whose composition and criteria of decisionmaking were also denounced by anarchists, defined the sanctions that protected these rules, which were enforced by violent State apparatuses such the police or the army. Anarchists therefore saw the State as "authoritarian" because it was perceived as an organization that exercised power in a centralized form. As a consequence, all the social order it created was permeated by subordination and coercion (Descallar, 1984: 197-198). As Bakunin wrote: "whoever says State necessarily says domination, and consequently, slavery" (Bakunin, 1950: 49). While these struggles were seemingly disparate ones against inter alia wage slavery, organized religion, war, and colonization - anarchists viewed the matrix of domination as effects that originated from the State (Hodgson, 2007: 6-7).

\subsection{RESITANCE \& POSSIBLITIES}

Classical anarchists refused to negotiate with the State, and instead, believed that eradicating domination would require the State's immediate destruction. While the Marxist strategy encouraged the temporary capture of State power with the aim of ultimately dissolving it, anarchists believed that the masses should immediately organize resistance outside the State-form, and while doing so, the possibility of living in anarchy -a society without sovereignty, without political power, and without capitalist modes of production - would be revealed. This dual strategy can be understood as exerting a politics of prefiguration where activists attempt to directly confront institutions of 
domination by organizing it according to the values and principles they wish to live by.

\section{Direct Action \& Prefigurative Politics}

To resist political domination and build a future anarchist society, classical anarchists advocated for a social revolution that would destroy the State, its machinery (the police, the army, the prison), and, therefore, its administration of capitalist social relations. The goal of this revolution would be to replace these State apparatuses with decentralized, nonhierarchical forms of social organization in which property and the means of production would be collectively owned. Whereas political revolution was viewed as involving a mass being led by a small group of charismatic individuals who would take power and then install a new State and thus another form of domination, social revolution was intended as an uprising of the masses with no formal leaders or hierarchies. Social revolution, anarchists argued, would be based on the desire for freedom and the ethics of mutual aid, social solidarity, direct action, and autonomous self-organization. As Murray Bookchin explains:

"[a] movement that sought to promote a liberatory revolution had to develop liberatory and revolutionary forms. This meant...that it had to mirror the free society it was trying to achieve, not the repressive one it was trying to overthrow. If a movement sought to achieve a world united by solidarity and mutual aid, it had to be guided by these precepts; if it sought to achieve a decentralized, Stateless, non-authoritarian society, it had to be structured in accordance with these goals" (Bookchin, 1998: 180).

Classical anarchists believed that this social transformation could be achieved by the implementation of a series of direct actions against State-capitalist sites by the masses. Rather than simply make demands or negotiate, the notion of direct action is a political tactic that goes beyond "parliamentary and bureaucratic channels" to eliminate 
an immediate injustice, or to obstruct an unjust system or order (Conway, 2003: 508). ${ }^{6}$

The purpose is to disrupt and confront an injustice or unjust order, rather than to negotiate with those individuals who sustain it. What this suggests is that classical anarchists advocated a politics of prefiguration: the practice through which revolutionary subjects merge their ends with their means (Maeckelbergh, 2009: 67).

\section{The Future Anarchist Order}

While pre-revolutionary society consisted of man-made social contracts and a State that arbitrarily imposed decisions, for Bakunin and Kropotkin, a post-revolutionary anarchistic society would consist of free agreements and voluntary associations. They believed the latter society would create space for the desire and creativity of human essence to be expressed by establishing communities "freely, socially, and, above all, from below" (Kropotkin, 1968: 42-43.) Such a society, Bakunin posited, would not be perfect but would be far more egalitarian than before. He stated:

"I do not say that the peasants [and workers], freely organized from the bottom up, will miraculously create an ideal organization... But I am convinced that what they construct will be ... a thousand times better and more just... Moreover, this... organization, being on the one hand open to revolutionary propaganda... and on the other, not petrified by the intervention of the State...will develop and perfect itself through free experimentation as fully as one can reasonably expect in our times... [T]he abolition of the State, the spontaneous self-organization of popular life... will revert to the communes. The development of each commune will take its point of departure the actual condition of its civilization" (1971: 207).

Classical anarchists, therefore, asserted the importance of an organization that emerged from below, rather than utilizing a top-down command structure. This anarchist

\footnotetext{
${ }^{6}$ Wildcat strikes, property sabotage, and factory occupations are classic forms of direct action.
} 
approach to social organization was what Colin Ward calls "the theory of spontaneous

order," a theory that suggests that "a collection of people will, by trial and error" and "by improvisation and experimentation", evolve order out of their situation or crisis. It was believed that this order was more "durable and more closely related" to the needs of the people within a given community or terrain than any kind of externally imposed authority could provide (Ward, 1982: 31).

\section{Horizontal Federalism}

The concept of creative spontaneity, however, does not imply that anarchists did not envision alternative organizational models. On the contrary, anarchists anticipated and outlined very detailed schematics for a post-revolutionary society. Bakunin, for example, expanded Pierre Proudhon's theory of anarchist federalism, in which voluntary federations involving horizontal coordination among local autonomous groups would be established. This alternative was envisioned as a social organization to be "carried out from the bottom up, by the free association or federation of workers, starting with associations, then going into the communes, the regions, the nations, and finally, culminating in a great international and universal federation" (Ward, 1982: 26). Colin Ward observes that this form of federation functions as distributed networks, explaining that communes and syndicates would "federate together not like the stones of a pyramid, but the links of a network, the network of autonomous groups" (Ward, 1982: 26). 


\section{Anarcho-Collectivism}

The basis for Bakunin's federalism was to be provided by the absolutely autonomous commune, which "will always be represented by the majority of the votes of all the adult inhabitants... [with] men and women having equal rights" (cited in Pyziur, 1968: 131). In Bakunin's theory, society would immediately abolish private property in order to collectively own the means of production. Once collectivization took place, workers' salaries would be democratically determined depending on the difficulty of each job and the amount of labour contributed. These salaries would be used to purchase goods in a communal market. Bakunin proposed that officials and delegates would be elected for other societal tasks. To prevent the development of bureaucracy and hierarchies, their mandates would both temporary and revocable at any given moment. Local communities organized along these structures would unite in a free federation of communes for each province and, in turn, the provinces would merge to form a larger federation. Every human individual and every commune within the federation would have an inalienable right to secession. In Bakunin's opinion, this federation would solve the problem of the Stateless nations that were striving for their independence. But the main task of federalism was that of parceling out political power that would result in the total "annihilation of the State and of all political domination and power" (Pyziur, 1968: $130-131)$.

According to Bakunin, anarchist federalism and economic collectivism were only possible as a singular revolutionary event through a process of violent confrontation with the State. Bakunin asserted that existing States couldn't form the baseline perspective for a true federation. States must be totally abolished, and only after their complete 
destruction could a new federative structure be built (Pyziur, 1968: 131). Along with the use of direct action, Bakunin also advocated for the propaganda of the deed: direct acts of insurrectionary violence against the Bourgeois State by means of political assassinations and terrorism. Once this process of violent confrontation was complete, and the means of production were collectivized, then human emancipation would reach its finality. ${ }^{?}$

Kropotkin concurred with Bakunin in his belief that the goal of social revolution was to create a society where the functions of government would be replaced by free agreements growing out of the direct relations between 'free groups of producers and consumers.' He, too, expected this change to come about through the exertion of direct actions through which the masses 'would lay hands upon property and use it to meet their own needs without the mediation of State and capitalist forms' (1990:158). Moreover, Kropotkin agreed with Bakunin that the means of production should be collectively owned, and that society should organize through a form of direct democracy and voluntary federations.

\section{Anarcho-Communism}

Unlike Bakunin, however, Kropotkin believed that all wage-systems of labour needed to be abolished. While Bakunin proposed that individual labour could dictate goods received, Kropotkin strongly disagreed and argued that an anarchist society should always adhere to the socialist dictum: "from each according to his ability, to each

\footnotetext{
7 Bakunin wrote: "Thus, the social revolution will be made, and once revolution's foes have been stripped of all means of harming it, there will be no further need to proceed against them with bloody measures" (Bakunin, 1998: 164)
} 
according to his need." In his opinion, anarcho-communism should be based on the right

of free association/disassociation for individuals and groups and, furthermore, on the significant lowering of the amount of hours each individual was socially required to dedicate to necessary labour. As Kropotkin argued:

"...to recognize a variety of occupations as the basis of all progress and to organize in such a way that man [sic] may be absolutely free during his leisure time, whilst he may also vary his work, a change for which his early education and instruction will have prepared him - this can easily be put in practice in a Communist society - this, again, means the emancipation of the individual, who will find doors open in every direction for his complete development" (Kropotkin, 1968).

More importantly, Kropotkin distanced himself from the propaganda of the deed, and argued that "a structure based on centuries of history cannot be destroyed with a few kilos of dynamite" (cited in Billington, 1980: 417). This was not a rejection of violent tactics per se, but, rather, a belief that stronger emphasis should be placed on Proudhon's concept of worker self-management (autogestion). For Kropotkin, if society was to succeed in organizing the economy in a post-revolutionary society, workers must develop alternative systems within the body of capitalism and the State prior to a revolution. ${ }^{8}$ By building networks and practicing autogestion, industries and factories would eventually be operated by producers and consumers, which would simultaneously advance the destruction of the State (Kropotkin, 1968: 169). While still sharing an anti-reformist spirit by anticipating a coming revolution, Kropotkin regarded social transformation as an ongoing process that required a variety of tactics, rather than a singular insurrectionary

\footnotetext{
${ }^{8}$ Kropotkin wrote: “....we maintain that already now, without waiting for the coming of new phases and forms of the capitalist exploitation of labor, we must work for its abolition. Rather we must already now, tend to transfer all that is needed for production - the soil, the mines, the factories, the means of communication, and the means of existence, too - from the hands of the individual capitalist into those of the communities of producers and consumers" (Kropotkin, 1968: 169).
} 
event.

While Bakunin and Kropotkin differed on a number of tactical and organizational practices, we can see that they concurred on four ethical principles: (1) an opposition to hierarchies; (2) the advocacy of decentralized modes of organization; (3) a commitment to freedom and autonomy; and (4) an opposition to (Marxist) revolutionary vanguardism. Moreover, both thinkers saw anarchist politics as a moral opposition between society and the State; as a moral opposition between power and humanity itself. As noted above, anarchists perceived natural law as antithetical to "artificial" power. They rejected Hobbes's negative perception of human nature, and instead, believed that the morality and rationality inherent within the human subject came into conflict with the irrationality and immorality of the State. Classical anarchists thus conceived power as "transcendent to the social realm and imposed from above." The 'masses' represented a location outside of power and a pure place of resistance from which the "essence towards cooperation and sociability would arise if relived of the burden of the State and of capitalism" (Hodgson, 2007: 9-100).

\section{Breaking the Foundation}

However, it is here - in the essentialized notions of power, subject, and domination, and humanist assumptions of natural law and sociability - where contemporary anarchist literature has attempted to break from its ontological foundation. This break, however, is not a complete dismissal of anarchistic politics. As I shall demonstrate in chapter two and three, the four basic principles that were shared by both Bakunin and Kropotkin continue to serve as the impetus for contemporary anarchist 
praxis. The trend, however, indicates that the latter is attempting to strip away the essentialist and humanist traits in order to strengthen the anarchist project, although left behind are several paradoxical challenges.

In the next section, I will explore how anarchists have begun appropriating the works of Michel Foucault, Jacques Derrida, among other 'poststructuralists' to both deconstruct classical anarchism's ontological foundation, and also to move beyond it. As we shall see in coming pages, an analysis of contemporary literature reveals that many of today's anarchists problematize the essentializing concept of the human subject and the failure to consider forms of power outside of the State. I believe that this rightfully forces us to re-consider my initial questions. In other words, from an anarchist perspective, the matrix of domination is no longer understood as derived solely from the State or sovereign. It also forces us to reconsider how one can resist this matrix, and whether there are anarchic possibilities of existing outside of it.

\section{THE EMERGENCE OF A POST-UTOPIAN ANARCHISM}

\subsection{POWER \& DOMINATION}

\section{The Postmodern Challenge}

According to some contemporary anarchists, revolutionaries such as Kropotkin and Bakunin were not successful in their resistance against the State because they failed to grasp the notion that oppressive power relations were not distributed from an archaic centre, whether that centre was a king, the bourgeoisie, or the State. As noted earlier, classical anarchists believed that the struggle against the matrix of domination was between the 'masses' (humanity) and the Sovereign (the State). Contemporary anarchists, 
however, go beyond this premise, and indicate that many oppressive power relations are, in fact, spread throughout social fabrics. This does not mean that anarchists no longer perceive the State as a site of domination but rather, they acknowledge that a politics of resistance that merely attacks the State, or anticipates its destruction will be inadequate in dismantling the matrix of domination.

Contemporary Anarchist scholars, such as Todd May, Saul Newman, and Richard Day for instance, all note that while oppressive power can be concentrated by the State it is no longer confined within it. They suggest instead that the matrix of domination gender, racial, familial, educational, sexual, among others forms - is an elastic concept that requires each system and regime to be grounded, analyzed, and critiqued within its own particular context and realities (see May, 1994; Newman, 2001; Day, 2005). Here, the suggestion is that anarchists must not only (re)-theorize the location(s) of domination, but also (re)-consider their tactical methods in resisting against it. Otherwise, the existing anarchist theory/praxis will be both unsuccessful and dangerous as it would inevitably (re)-produce new forms of domination. This point is further elaborated by the Invisible Committee, who note that an anarchic social transformation can only be successful insofar as one can defeat:

"...both authority and the need for authority, property and the taste of appropriation, hegemony and the desire for hegemony...Destruction [of the State will] never been enough to make things irreversible...In these times, the response to the decentralization of power is the end of revolutionary centralities...Power is no longer concentrated in any given place in the world; Power has become this world itself, its flows and its avenues, its men and its conventions, its codes and technologies (2009: 131). 
Without a centre to attack from, the suggestion of the Invisible Committee is that resistance against oppressive power relations must adopt a different strategy than what is embodied in classical theory/praxis. This is because the reliance on an essentialist human subject, and the advocacy of revolutions via programmatic blueprints and schematicsrisks becoming authoritarian as they merely reverse hegemonic relationships (see Day, 2005). The idea is that if anarchists do not seek to capture existing political structures, but instead seek to destroy them to open up space for alternative social organization, then social transformation should also take form in the same way that power is constituteddecentered (see Hodgson, 2007).

We can begin to see that contemporary anarchist literature has clearly taken inspiration from poststructuralist concepts and theories; a point which I shall now elaborate on. Before I begin my analysis, however, it is important to note here that while poststructuralist thinkers indeed share an affinity with anarchism, they have never explicitly aligned themselves with the anarchist tradition and therefore I do not suggest that their work is anarchist per se. Rather, I hope to demonstrate how their work has played a strong role in influencing and challenging anarchistic thinkers. While his work is not incorporated dogmatically, the most influential poststructuralist thinker is Michel Foucault, whose analysis of power and subjectivity has made a significant contribution to contemporary anarchistic thought.

\section{Foucault's 'Microphysics' of Power}

In his historiographical studies, Foucault suggests that power is no longer confined within the institution of the State. Instead, he shows that power should be analyzed as a 
polyvalent force that runs through multiple sites throughout the social body; it may run through the prison or the mental asylum, or through constructing various knowledges and discourses such as psychiatry or sexuality. This is not to suggest that a sovereign cannot asymmetrically wield power, as Foucault clarifies that power can be colonised by a greater force. However, it should not be seen as belonging or deriving from it, because the State can only operate on the basis of other, already existing power relations (1980: 122). As Foucault writes:

"Our object is not to analyze rule-governed and legitimate forms of power which have a single centre, or to look at what their general mechanisms or its overall effects might be. Our object is, on the contrary, to understand power by looking at its extremities, at its outer limits at the point where it becomes capillary; in other words, to understand power in its most regional forms and institutions, and especially at points where this power transgresses the rules of right that organize and delineate it, oversteps those rules and is invested in institutions, is embodied in techniques and acquires the material means to intervene, sometimes in violent ways (2003: 27-28)."

As we can see, in Foucault's analysis power is not merely a function of institutions; the institution is a function, or an effect, of power. Power flows through institutions, it does not simply emanate from them. The institutions are merely an assemblage of various power relations. This means that social relations cannot change if the mechanisms of power that function outside, below, and alongside of the State, on a more minute and everyday level, are also not changed (Foucault, 1980: 60). However, what is crucial about Foucault's analysis is the notion that power cannot be regarded as a phenomenon of mass and homogenous domination, as Bakunin and Kropotkin perceived. Power is not something that is divided between those who have it and hold it exclusively, 
and those who do not have it and are subject to it (see May, 1994). Foucault contends that power:

"...is never in the hands of some, and is never appropriated in the way that wealth or commodity can be appropriated. Power functions. Power is exercised through networks and individuals do not simply circulate in those networks; they are in a position to both submit to and exercise this power. They are never inert or consenting targets of power; they are always its relates... power passes through individuals, it is not applied to them" (2003: 31).

According to contemporary anarchists, if one accepts Foucault's analysis it renders any desire to 'abolish power' misguided, as power can neither be abolished or possessed. In fact, in their assessment, classical anarchists had failed to appreciate that their envisioned modes of organization-such as decentralization, mutual aid, and solidaritywere also forms of power relations because power, in Foucault's analysis, is a series of ongoing strategies: a mode of action upon the action of others (Foucault, 1982: 221; see also May, 1994). This means that one can never be outside of power, as "there are no margins for those who break with the system to gambol in" (Foucault, 1980: 141). As May notes, by looking at an arrangement of power anarchists must ask whether it is creating something that is bad for those who are subject to it. But, in answering this question they cannot simply say that since it is a power relationship it is bad (May, 2009: 14).

However, just because one can never be free from power does not necessarily infer that one can never be free from domination. In Foucault's analysis, relations of power become relations of domination when the free and unstable flows of power become blocked and congealed, 'when power relations form unequal hierarchies and no longer allows reciprocal relationships' (Foucault, 1988: 3). Thus, it is these relations of 
domination that form the basis of institutions such as the State. In other words, today's anarchists recognize that the State is merely an effect of power relations that have crystallized into relations of domination, and that its immediate abolishment will be ineffective in dismantling the matrix of domination.

\section{The Matrix of Domination}

Because of the influence of Foucault, anarchic conceptualizations of domination tend to mobilize a fluid concept that can account for various systemic features of society, whereby groups and persons are "controlled, coerced, exploited, humiliated... [and] discriminated against" (Gordon, 2008: 32). Anarchists argue that they are not attempting to abolish power relations, but are instead seeking to uncover, challenge, and ward off those that are a part of an assemblage within a matrix of domination; the web of practices and institutions that have the effect of perpetuating and multiplying various forms of interlocking oppression (Day, 2005: 6). Uri Gordon, for example, writes that an anarchic understanding of domination draws attention to this multiplicity of partial overlaps between different experiences that are struggled against, constructing "a general category that maintains a correspondence between experiences which remain grounded in their own particular realities" (2008: 32).

Domination therefore is ubiquitously understood as power. Invoking a Foucauldian analysis, not only do anarchists speak of domination of the State and its apparatuses, but also about a worker being dominated by their boss, or a wife being dominated by her husband. As Gordon notes, one can be dominated when there is no way of "opting out" of an oppressive relationship. For example, women or people of color can encounter 
discrimination, access barriers and even derogatory behaviour towards them throughout everyday life, but they may not be able to remove themselves from these relationships. It is in these circumstances when institutions or regimes of domination may arise. Unlike racism and sexism, which generally refer to an individual or group's attitudes of prejudice and bigotry, institutions or regimes - such as patriarchy, wage slavery, or white supremacy - become terms to articulate certain types of domination because they refer to defining features of social relations. This does not mean that anarchists believe all forms or systems of domination operate identically, but that naming the particular form of domination enables them to "transcend specific antagonisms towards the generalized resistance that they promote... [i]f there is one distinct starting point for an anarchist approach, it is this act of naming" (Gordon, 2008: 33).

Moreover, the fluid concept of domination also conforms with the commitment to decentralization in the process of resistance and social transformation. For anarchists, resistance proceeds through confrontation with any relationship or institution that administrates domination. As Gordon notes, anarchists believe that any act of resistance can be, in the barest sense, anarchistic when the individual perceives it as "a particular actualization of a more systemic opposition to domination." For example, resistance against the imprisonment of refugees and illegal immigrants becomes anarchistic when it is directed towards the State, since it is the State that is the ultimate source of immigration policies (Gordon, 2008: 34).

By incorporating a broader analysis of what constitutes domination, we can see that the modern anarchist project has begun to move beyond a politics that simply prioritizes the abolishment of the State. In fact, many of today's anarchists take an approach similar 
to Foucault's Ethics of a Concern for Self, perceiving anarchism as a movement towards

building a society where power relations would be exist in as benign a form as possible.

They no longer focus on eliminating power altogether; something that is virtually

impossible (Gordon, 55; see also Day, 2005; Hodgson, 2007) ${ }^{9}$ Although there continues

to be ontological assumptions, anarchists believe that naming and highlighting the

various forms of domination is a necessary act in order to show that domination also

comes from the 'same world as power' (see Newman, 2001). As demonstrated above, our

everyday actions inevitably involve power. These everyday power relationships,

however, are also unstable; they always have the potential to form into relations that

dominate us. As Foucault writes:

"My point is not that everything is bad, but that everything is dangerous...If everything is dangerous, then we always have something to do. So my position leads not to apathy but to a hyper-and pessimistic activism" (1984: 238).

Here, anarchists draw upon Foucault's analysis to further contend that we must be constantly on our guard against the possibility of domination. In other words, we must always be aware of its risk — of the possibility that our own actions, even political actions against domination, can easily give rise to new forms of domination. This is especially true in an era of biopower —or, the technology of power that regulates the biological livelihood of people and manages them as groups and identities.

\footnotetext{
${ }^{9}$ Foucault writes: "The idea that there could exist a state of communication [referring to Jürgen Habermas] that would allow games of truth to circulate freely, without any constraints or coercive effects, seems utopian to me. This is precisely a failure to see that power relations are not something that is bad in itself that we have to break free of. I do not think that a society can exist without power relations, if by that one means the strategies by which individuals try to direct and control the conduct of others. The problem, then, is not to try to dissolve them in the utopia of completely transparent communication but to acquire the rules of law, the management techniques, and also the morality, the ethos, the practice of self, that will allow us to play these games of power with as little domination as possible" (1997: 268).
} 


\subsection{THE TRAP: ESSENTIALISM}

\section{Biopower \& Embodied Subjectivity}

Along with his analysis of power as circular and decentred, Foucault also tracks the emergence of a particular technology of power, commonly exerted by modern States, which he calls biopower; the literal power over bodies through numerous and diverse techniques for achieving 'the subjugations of bodies and the control of populations.' As Foucault clarifies, biopower is:

"[a] set of mechanisms through which the basic biological features of the human species became the object of a political strategy, of a general strategy of power, or, in other words, how, starting from the 18th century, modern Western societies took on board the fundamental biological fact that human beings are a species" (2007:1).

What's unique about biopower is that it relates to the government's concern with protecting the life of the population rather than bringing death. This is done, for example, through the regulation of the human body as well as the production of other technologies of power, such as the concept of sexuality. For anarchists, this productive aspect is what makes biopower especially dangerous, as it allows the 'rational' justification of whatever means biopower techniques must use in its quest for continuous domination. As the anonymous Tiqqun writes in the Theory of Bloom:

"We evolve in a space that is entirely controlled, entirely occupied, by the Spectacle on one hand and by Biopower on the other. And what is so terrible about this control, about this occupation that they force us to endure, is that it is not something we might rebel against a definitive gesture of rupture, but with which we can only compose strategically. The regime of power under which we live does not at all resemble the mechanisms of restriction, of purely repressive coercion, that could have circulated under the administrative monarchies, the expired concept of which lived until a recent date, even within biopolitical democracies. These mechanisms are the only enemy recognized by revolutionary movements. The contemporary form of domination is, on the contrary, essentially productive. On one hand, it rules all the manifestations of our 
existence - the Spectacle; on the other hand, it manages the conditions of the Spectacle - Biopower" (Tiqqun, 2010).

In the History of Sexuality, Foucault confronts the sexual revolution of the 1960's and 1970's by arguing that it is not as emancipatory as some believe. On contrary, Foucault contends that sexuality has not been liberated because for the past several hundred years it is precisely the concept of sexuality that has come to define us. Rather than enduring a Victorian repression of sexuality that was only liberated in the latter part of the twentieth century, we have instead become beings of sexuality. The sexual revolution is a symptom of our historical legacy, and not a revolt against it.

What Foucault suggests is not that people didn't have sex before the seventeenth and eighteenth centuries, but that a variety of practices converged during that era to make us think of ourselves and indeed produce ourselves as beings of sexuality.

For instance, homosexuals, as a category of sexuality, are not the product of a conspiracy of people who hate those who have sexual relations with members of the same sex. Rather, homosexuals are the product of a complex network of practices that have placed sex at the centre of our sense of who we are. In other words, homosexuals are oppressed because they have become homosexuals, which, in our society, is an oppressive position to occupy (Foucault, 1980; see also May, 2009: 13-14). Thus, in Foucault's analysis, identity is formed through regulatory apparatuses that defines and subjects individuals. Identity creates new types of peoples: the homosexual, the criminal, the madman, and so on. These discourses attach new meanings to acts and behaviour and seek the 'truth' about them. The individual thus becomes describable and analyzable 
through innovations in social science, such as statistical data, that can become documented (McLaren, 2002: 122).

\section{The Paradox of Anarchist Subjectification}

For Foucault, the problem with accepting and participating in these identities is that it suppresses differences and recreates sexual hierarchies, entrenching socially constructed 'discourses', 'truths', and 'norms' about the identity, rather than seeking their dissolution. This construction and categorization is formed trough exclusionary practices that differentiate between the 'normal' from the 'abnormal'. Because 'normal' consists of the majority or dominant identity, those who deviate from this norm are marginalized, and this marginalization has both psychological and material effects. For example, a particular group may have less economic power and access to resources, or individuals may come to internalize oppression. Thus, Foucault believed that adherence to a particular identidy inhibited the possibility for change, and warned against this stasis of identity (McLaren, 2002: 122-123). This is because he believes the relations we have with ourselves are "not ones of identity, rather, they must be relationships of differentiation, of creation, of innovation" (Foucault, 1997: 166).

It is here where Foucault's work confronts anarchism with the most difficulty, as it forces anarchists to reconsider whether their own practices and tactics(re)-produce a set of new forms of oppression and contradictions. Torrance Hodgson, for example, writes that Foucault's work necessitates anarchists reject a revolutionary subject, be it in 'the people,' workers, proletariat, women, homosexuals, indigenous peoples, or even themselves: 
"A rejection of essence, strategic or otherwise, necessarily means a rejection of social struggles that have as their foundational and revolutionary subject particular oppressed identities, commonly known as 'identity politics" (2007: 17).

In other words, if the anarchist project is a struggle against the matrix of domination, it will also need to abandon the anarchist as a subject. Alex Trocchi similarly argues that the anarchist identity is merely another product of biopower, and unless there are ways of developing a politics of resistance that moves beyond identity, an essentialized anarchist "subject" will become an obstacle in the possibilities of radical alternatives. Instead, what is needed is a new revolutionary subject as still yet-to-come (see Trocchi, 2011; Tiqqun, 2011). To move beyond identity, a revolutionary subject must be conceptualized as an inclination, an ongoing tendency towards the destabilization of practices of domination, "an orientation that casts practices already extant in doubt, and the continual creative experimentation with new forms of social organization that tend towards the increase of decentralized power relations..." (Hodgson, 2007: 17). Anarchists, however, recognize this to be particularly a difficult and paradoxical task. As we shall see further below, and in the subsequent chapters, anarchists have differed from Foucault here, as they have not completely abandoned identity. Instead, they have sought to develop a politics of singularities rather than hegemony - a politics that does not abandon strategic essentialism as means of attempting to go beyond it, but still views the revolutionary subject and identities as yet-to-come. Where anarchists have attempted to completely abandon their essentialism, however, is in the humanist foundation of the tradition and its tactics of resistance via counter-hegemony (see Day, 2005; Tiqqun, 2011). 


\section{Problematizing Humanism}

As discussed earlier, classical anarchists believed that the State must be immediately destroyed because it constrained the authentic human essence. By comparison, today's anarchists draw on Foucault to argue that human nature, and thus the derivate notion of justice, is a socially constructed norm (see Hodgson, 2007; Day, 2005). In a debate with anarchist Noam Chomsky, Foucault argued:

"...you can't prevent me from believing that these notions of human nature, of justice, of the realisation of the essence of human beings, are all notions and concepts which have been formed within our civilisation... and one can't, however regrettable it may be, put forward these notions to describe or justify a fight which should - and shall in principle - overthrow the very fundaments of our society" (Chomsky \& Foucault, 2006).

For anarchists, this means one can no longer derive notions of justice from assuming a natural human essence that contains cooperation, mutual aid, or sociability. Scholars such as May and Day contends that because classical anarchists mistakenly considered social transformation as the removal of State power so as to liberate the human essence, they also identified anarchy with a unique event: the revolution and the organization of a particular and fixed set of arrangements. Classical anarchists harnessed "a vision of a better society" when they should have instead been thinking about "better States," "possible futures" and "visions of alternatives" (see May, 1994; Day, 2005). Drawing on Foucault's theory, anarchists argue that providing blueprints and schematics risks falling victim to the same essentialist and authoritarian trap as the Marxist revolutionary strategy. In other words, to argue that society should adapt the structures of federalism and organize through direct democracy for the purpose of liberating 'the people' is still a concept based on an idea about what constitutes human subjectivity and 
what human needs are. This concept merely replaces the Marxist revolutionary rhetoric with an anarchist one, which contradicts and threatens a project of dismantling the matrix of domination (Newman, 2001; Hodgson, 2007). Richard Day calls this the hegemony of hegemony. By this he refers to the assumption that effective social change can only be achieved simultaneously and en masse, across an entire nation or supranational space. Day has argued that the history of Marxist revolutionaries have followed this logic of hegemony in seeking State power, hoping to reverse the relationship between the dominated and the dominators. Certain elements of classical anarchism, however, also fell into this trap (Day, 2005)

This rejection of mass revolution, and the dangers of subjectivity, however, raises the question of how anarchists should envision resistance without falling into an essentialist or hegemonic trap. While anarchists have been strongly influenced by Foucault, they acknowledge that he was often very reluctant to engage in either normative or strategic discussions. Foucault maintained he was offering intellectual tools for struggle, as he believed that the terms of struggle should be decided by those who resist rather than by intellectuals. This is where anarchists have begun looking at other poststructuralist thinkers for finding ways of escaping essentialist and hegemonic traps. While sharing a number of sympathies with Foucault, many contemporary anarchists have invoked Jacques Derrida's deconstructive practice as offering possibilities of moving beyond humanism and identity politics. 


\section{Derrida's 'Deconstructive' Practice}

Like classical anarchists, Derrida's theory also reveals origins of State law as

violence that is 'disavowed yet inscribed within the structures of the law', which is made possible by its mystical foundation: an autographic fiction (Newman, 2005: 92-93). As

Derrida writes, the total unity of a nation:

"is not identified for the first time except by a contract-formal or not, written or not- which institutes some fundamental law. Now this contract is never actually signed, except by supposed representatives of the nation which is supposed to be "entire" [State]. This fundamental law cannot, either in law or in fact, simply precede that which at once institutes it and nevertheless supposes it: projecting and reflecting it! It can in no way precede this extraordinary performative by which a signature authorizes itself to sign, in a word, legalizes itself on its own without guarantee of a preexisting law." (Derrida 1992, 20)

In Derrida's view, this foundation in violence does not mean that the origins are "illegal" but that they are neither legal nor illegal. According to Derrida, the authority that supposedly grounds law is only legitimized once it is instated. This means that the authority upon which law is established is non-legal because it had to exist prior to law. The initial act of instituting law is, therefore, illegitimacy: a violence. For Derrida, this violence occupies a position of "undecidability" because it is something that is both inside and outside the law. Just as classical anarchists highlighted the paradox of the social contract and its inherent violence, Derrida also sees violence as not antithetical to the law and its structures but internal to the law itself. ${ }^{10}$ The authority of law can therefore be questioned from the perspective of its own ambiguity. Law can never "reign

\footnotetext{
${ }^{10}$ Derrida uses Walter Benjamin's example of the modern police. Benjamin perceives the police as the worst case of legalized perversion and sanctioned violence. He writes, "Police violence is emancipated from both conditions. It is law making, for its characteristic function is not the promulgation of laws but the assertion of legal claims for any decree, and law-preserving, because it is at the disposal of these ends ... Its power is formless, like its nowhere tangible, all-pervasive, ghostly presence in the life of civilised states." (Benjamin 1986, 286-87).
} 
absolute because it is contaminated by its own foundational violence" (Newman, 2005: 127; see also Derrida, 1992).

As we can see, Derrida's analysis of law as mythical, authoritarian, and inherently violent resembles the anarchist critique. However, unlike classical anarchists who criticized "artificial law" in contrast to the morally superior "natural law", anarchists highlight that Derrida does not allow such a privileged standpoint. On the contrary, they argue that one could use the practice of deconstruction to illustrate that the so-called natural law that classical anarchists presented as a pure alternative, is in fact, not so pure because "its identity is contaminated by the political authority it is juxtaposed to" (Newman, 2001: 127; Day, 2005). By remaining within the framework of Enlightenment humanism, today's anarchists argue that classical anarchists trapped themselves within the scope of their own critique. Just as Bakunin and Kropotkin accused Marxism of replacing one form of authority with another, classical anarchists too merely challenged the form of authority, but not its place. Their concept of natural law and their belief that a social revolution would occur through realizing the human essence only supplemented the authority it had exposed. In other words, for contemporary anarchists, Derrida's theories can help one further understand that the revolutionary anarchist project is counter-hegemonic and thus risks becoming domination, which is in direct contradiction to its initial foundations (Newman, 2001: 121-122; see also Day, 2005; Hodgson, 2007; May, 1994). 


\subsection{ESCAPING THE TRAP}

\section{Possibilities of Resistance: Singularities \& Différance}

However, Derrida does not suggest that there are no possibilities for theorizing

resistance. For Derrida, deconstruction cannot simply work within the structures of logocentric philosophy; nor can it completely work outside of them. Instead, deconstruction traces a path of undecidability between the two positions. For anarchists, this avoids the trap of place: it establishes neither a place of power, nor a place of resistance, which anarchists believe are two sides of the same logic of domination.

Rather, Derrida constructs a path between power and resistance, disrupting the identity of both terms (see Newman, 2001; Derrida, 1994). For anarchists such as Newman and Hodgson, this is important because it points to the possibility of an outside - an outside of resistance-on the inside which is not part of the binary structure of inside/outside. To position oneself entirely on the outside of any structure as a form of resistance is only to reaffirm, in a reversed way, what one resists. However, the idea of an outside created by the limits of the inside, allows us to conceive of a politics of resistance which does not restore the place of power (Newman, 2001: 125; see also Hodgson, 2007). Anarchist Hakim Bey, who writes about the possibility of a Derridean influenced Temporary Autonomous Zone (TAZ), presents one example:

"The TAZ is like un uprising which does not engage directly with the State, a guerrilla operation which liberates an area (of land, of time, of imagination) and then dissolves itself to re-form elsewhere/elsewhen, before the State can crush it" (1991).

Moreover, unlike the classical anarchist place of resistance located in an essential human subjectivity, this outside located by Derrida's deconstruction also has no stable identity. In other words, this outside identity does not have to be anarchist, communist, or 
any other political categorization, but rather, it can be continually be reinterpreted and jeopardized - a revolutionary identity as still yet-to-come (Newman, 2001: 124-125; see also Derrida, 1994). Yet, unlike Foucault, this does not mean one has to completely abandon subjectivity itself. Instead Derrida believes this identity as yet-to-come can exert a politics of differrance, in which there is "no longer the oppositional relationship of division that it became in the era of identity politics, but becomes also an expression of commonality through an overlapping with other differences to which each difference defers for its own meaning" (Maeckelbergh, 2009: 173; Derrida, 1994; 1982; 1973).

\section{Possibilities of Social Transformation: (Re)-thinking Law, Justice, \& Emancipation}

If any social transformation is to avoid reestablishing the authority of law, then law, for Derrida, must also be distinguished from justice. In Derrida's theory, law is merely

the general application of a rule, whereas justice is an opening of law to the Other. Justice exists in a relation of alterity to law, and opens the discourse of law to an outside. Justice itself cannot be deconstructed. For a decision to be just, it must account for the singularity denied by law, and it must be different each time. It cannot be the mere application of the rule, but must continually reinvent the rule. According to anarchists such as Newman, if we are to accept Derrida's theory, then justice becomes the experience of the impossible because it always exists in a state of suspension and undecidability. It, like the identity of the radical outside, is the promise of something yetto-come which can never be completely grasped, otherwise it would cease to be justice and would become law. Justice is an "event" that opens itself to the other, to the 
impossible. Its effects are always unpredictable because it cannot be determined as law can be (Newman, 2001: 128; Derrida, 1992).

Since justice in Derrida's theory occupies an ethical ground that cannot be reduced to law or political institutions, Newman argues that it opens up the possibility for social transformation. This transformation is not an absolute destruction, but a reformulation that unmasks its problems and contradictions and leaves open the possibility of a continual and unpredictable reinterpretation. Newman argues that the classical anarchist discourse of emancipation does not necessarily need to be rejected, as in Foucault's theory, but rather it could be reformulated in this manner. While the Enlightenment ideal of emancipation has the potential for becoming a discourse of humanist domination, it can also become a discourse of liberation if it can be "unmoored" from its humanist foundations and re-founded as non-place. It is possible to free the anarchist discourse of emancipation from its essentialist foundations by expanding it to include other political identities and struggles that were previously neglected. In other words, the discourse of emancipation can be left structurally open, such that its content would no longer be limited or determined by its foundations (Newman, 2001: 127-129).

\section{The Politics of Becoming: Beyond Revolution}

In light of both Derrida's and Foucault's critique, we can see that today's anarchists view radical action as a process of discovering new spaces for experimentation. Not only do anarchists deconstruct and challenge existing forms of domination, but also they are interested in creating alternative spaces of an outside from the inside. Moreover, because there is no "archimedean point for change", and no final 
goal or liberated condition, anarchism is perceived as a continuous challenge against the matrix of domination that is an imperfect but present tense experiment. The idea is that micro changes will never achieve a utopian finality. Instead, there is "no final struggle, but a series of partisan struggles on a number of fronts." Revolution is no longer a final stage achieved by a singular event, but rather, perceived as "an orientation towards social experimentations", and a constant 're-evaluation that involves fighting against tendencies of domination already extant, and those that (re)appear'. It is a type of revolution not as a final stage, not a being, but a becoming, which is an eternally prefigurative politics (Hodgson, 2007: 18-19).

The advocacy of alternative spaces and decentered resistance, however, does not suggest that today's anarchists necessarily oppose mass-scale political and social revolutions. To do so, in their opinion, would be to hegemonize the field of social change (see Day, 2005). Instead, anarchists argue that a revolution - defined as the complete eradication of macro-political domination, for the purpose of constructing nonauthoritarian alternatives - is likely to be successful in areas that have not been subject to the "full penetration of the State-form into practices of everyday life," and where "alternative practices have survived" (Hodgson, 2007: 22). This is why, for example, the Spanish anarchists during the 1936-1939 Civil War were temporarily effective in developing alternative methods of social organization. The same analysis can also be made of the modern Zapatista uprising in Chiapas, Mexico, which was inspired partly by anarchism. As Day writes:

"...the example of the Zapatista autonomous zones is interesting in that it represents a successful attempt to achieve a critical mass in a circumscribed geographical space, in a way that is particular to that space, to the subjects, structures, processes and histories that make it 
what it is. It is unlikely for example, that sites for experimentation could be secured by armed rebellion in the global North, due to the much greater forces of violent repression under the command of these States and the long-standing docility of most of the population. At the same time, though, the Zapatista example is not entirely incommunicable certain elements of this struggle can be creatively appropriated elsewhere" (Day, 2005: 206).

The purpose of this critique is not to reject the very idea of revolution but to argue that those interested in radical change should not be preoccupied with revolution and neglect other ways of advancing this goal. As we shall see in the third chapter, anarchists have not completely rejected violent tactics such as property destruction, sabotage, and police confrontation. However, instead of targeting individuals with physical violence with the purpose of abolishing the State-form, many anarchists call for a social insurgency that attempts to temporarily "liberate" an individual from the constraints of repressive power and domination. It is believed by many that these insurrectionary tactics prefiguratively open space for radical alternatives, thus highlighting the possibilities of a militant anarchic resistance that can transcend the limitations of counter-hegemonic politics.

\section{Towards a Post-Utopian Anarchism}

The critique of revolution also does not suggest that anarchists are anti-utopian. As David Graeber writes, the problem with previous revolutions and utopias is not that that they were utopian, but that leaders, such as Stalin and Mao, took their own dreams for scientific certainties. This led them to believe that they had a right to impose their visions through a machinery of violence (Graeber, 2009). Rather than seeing utopia as a blueprint for a future post-revolutionary society, contemporary anarchists (re)-conceptualize utopia 
as a "moment of exteriority which punctures and displaces the existing hierarchical and repressive order" (Newman, 67: 2010). Like the (re)-conceptualized concepts of resistance, revolution, and subjectivity, utopia is also understood as a future that is yet-tobe created, which will never be created in exactly the way it is envisioned. For anarchists, reconceptualising utopia in this manner is crucial as it allows us to distance ourselves from the existing order, to see its limits; to understand that it can be transcended, and that there are better ways of living (Newman, 67:2010).

\section{Concluding Remarks: From Praxis to Theory}

Throughout this chapter, I have tried to provide a brief trajectory of anarchist theory. More specifically, I have tried to demonstrate how anarchist politics has shifted from a revolutionary humanist project seeking to emancipate the human subject from the State, to a radical ethics of practice - a politics of becoming - that continuously struggles against the entire matrix of domination. In doing so, I attempted to answer a set of questions about what anarchism is, what constitutes domination, how one could resist, and whether there are possibilities of social transformation. I have demonstrated, for instance, that a new kind of anarchism has emerged, one that does not completely dismiss its initial foundation, but (re)-formulates it towards a post-utopian dimension. As we shall see in the subsequent chapters, this trend continues to advocate classical anarchism's decentralized, horizontal, and network-based anti-authoritarian politics that rejects Marxist vanguardism. However, this trend towards what I call post-utopian anarchism, not only encompasses a broader and more fluid range of where regimes of domination exist, but also (re)-conceptualizing and abandoning concepts surrounding the 
revolutionary subject, utopian desires, and hegemonic tactical strategies in order to limit, ward off, and contain the matrix of domination.

However, there remains more questions that need to be further explored. We have seen, for instance, that both Bakunin and Kropotkin perceived power as synonymous with domination, which was emanated from a centralized entity. We have also seen that classical anarchists had either advocated or anticipated a coming revolution. However, as the poststructuralist inspired work of May, Hodgson, Newman, Day and a host of other contemporary anarchist scholars have demonstrated, anarchists are starting to no longer believe that domination is exclusively a State phenomenon. Moreover, anarchists have begun to perceive a singular revolutionary project as highly problematic and ineffective. This inevitably raises the question: how do anarchists resist against domination in an era where power and domination is fluid? How does it move beyond revolutionary programs that only create a new set of contradictions and hegemonic traps? To answer this, I believe we must further explore the notion of direct action and how it is exerted in practice.

As explained earlier, anarchists have always emphasized the use of prefigurative politics by encouraging direct action tactics and organizational forms that reflect key elements of their theory. The conflation of means/ends is intended to be synecdochic: a symbol that contains a small part that represents a large whole. The direct action tactics not only stand as a practical response to a given situation, but the ways in which they are organized also act as a symbol of the larger vision of societal change (Franks, 2003: 20). Under the premise of direct action, anarchists who propose social relations free of hierarchy and domination undertake their construction of these relations by themselves. 
Direct action is framed as a dual strategy of confrontation to delegitimize existing systems of domination, while simultaneously building radical alternatives. Thus, the collectives, communes, and networks in which anarchists are involved with today are themselves understood as the framework and visions for a different society (Gordon, 2008: 18).

Given that anarchists have come to abandon the traditional concept of utopia, there has been a larger emphasis on present-day experimentation. In other words, anarchists are spending a considerable amount of time prefiguring alternatives in their own practices against domination, including those that are considered more militant and violent. Thus, in the next chapter I will examine a wide range of activist practices, with an intention of understanding how they resist and intervene against the matrix of domination, and also how they prefigure, and sometimes create, radical alternatives to the existing order. 


\section{CHAPTER 2}

\section{TO HERE KNOWS WHEN: ON POSSIBILITIES \& IMAGINATION}

\footnotetext{
"The root of the prevailing lack of imagination cannot be grasped unless one is able to imagine what is lacking, that is, what is missing, hidden, forbidden, \& yet possible, in modern life."

-Situationist International
}

In the first chapter, we have seen that "classical" anarchists proposed alternative models for social organization, models that were believed to emancipate the human subject from the matrix of domination. In light of poststructuralist theory, however, contemporary anarchists have deconstructed classical anarchist thought to unmask its contradictions and limitations. However, rather than reject the classical anarchist project, contemporary anarchists have invoked a politics that parallels Derrida notion of singularities and différance. This illustrates an emergence of a new kind of anarchism, what some scholars consider post-utopian anarchism, which revolves around a politics of becoming, and a politics of revolution yet-to-come. How, then, do contemporary anarchists envision social organization? What are some 'possible' models anarchists offer as radical alternatives to the law and the State-form? How can these practices transcend the limitations of essentialism and counter-hegemony?

As discussed in the previous chapter, anarchists prefigure alternatives within their own organizational practices against institutions of domination. This practice of prefiguration attempts to remove the temporal distinction between the struggle in "the present towards a goal in the future; instead, the struggle and the goal, the real and the ideal, become one in the present" (Maeckelbergh, 2009: 67). These practices offer new radical alternatives that open the doors to post-utopian possibilities, although the 
alternatives are, indeed, imperfect and paradoxical. An exploration of prefigurative practices will therefore be fruitful in answering the questions posed above, as anarchic concepts such decentralization, mutual aid, and autonomy are not simply ethical values and abstract imaginations; they are also 'facts on the ground' where they are practiced, performed, and experimented with by activists on a daily basis (Gordon, 2008: 69). I begin the chapter with an exploration of 'macro' organizational practices by investigating spokescouncil assemblies. This "model" is an organizational tool that allows activists to coordinate the logistics of mass direct action in a decentralized manner. However, for anarchists, it also embodies a non-hegemonic vision for "autonomous" communities to voluntarily come together to make larger decisions that would extend beyond their terrain. Although there are paradoxical limitations, the model parallels Derrida's notion of singularities and différance, which in turn makes way for post-utopian possibilities.

The second half of the chapter will explore 'micro' organizational practices by investigating affinity group structures and its use of consensus decision-making. Anarchists believe that the practice of consensus prefigures a decision-making process that does not employ systemic violence by maximizing individual "autonomy" and making a commitment to community at the same time. Like spokescouncils, the practice of consensus opens the doors to a post-utopian decision-making process, as it attempts to escape the trap of law's violence. In its current form, however, the practice continues to be limited by its inability to completely abandon its humanist epistemology and structural contradictions. 


\section{I. 'MACRO'-ORGANIZATION}

Contemporary anarchism is often described as a network of informal interactions between a diversity of individuals and groups that are engaged in various political and cultural conflicts. The architecture is that of a decentralized global network of communication, coordination, and mutual support across 'autonomous nodes of social struggle, which lack formal membership or fixed boundaries' (Gordon, 2008: 18). If the anarchist milieu is diverse and fluid, then an important question arises: how do prefigurative practices envision "macro" organization? How would healthcare or transportation, for instance, be organized in a world without political boundaries? Furthermore, how do these practices move beyond the limitations of hegemonic politics? One possible "model" that anarchists offer is the spokescouncil assembly, although it continues to be limited by its inability to address groups or organization outside of its paradoxical norms.

\section{What is a Spokescouncil?}

A spokescouncil is a large, horizontal assembly of diverse affinity groups and organizations that meet voluntarily and temporarily for a common interest in challenging systems of domination(s) that directly affect them. An affinity group refers to a small and 'autonomist' group of activists that are closely familiar with one another, and who come together to undertake a specific action or project, whether in isolation or in collaboration with other groups (Gordon, 2008: 15)." Affinity groups, for example, tend to cluster

\footnotetext{
1 The term affinity stems from the Spanish grupos de afinidad, which was the basic constituent of the Iberian Anarchist Federation during the Spanish Civil war of 1936-1939. It originally referred to clusters of
} 
together to organize larger direct actions, such as shutting down or blockading a global summit meeting (G8/IMF/World Bank, etc). When organizing through a spokescouncil assembly, each affinity group selects a delegate or a spoke who is empowered to coordinate for their group. The spokes then come up with a set of proposals they believe might be acceptable to their collective, and discusses it with their group before implementing those decisions. What is important to note here is that spokes are not understood as "representatives" in the traditional political sense, as they do hold the power to execute decisions without the consent of their respective group. Rather, they are seen as correspondents or communicators, who are rotated by their respective affinity group. ${ }^{12}$ As I shall elaborate below, spokescouncils do not exclude participation in vertically structured groups, and thus hierarchical organizations such as labour unions or NGOs may send their presidents or executives as delegates.

In order to facilitate the process in a timely manner, spokescouncils often divide into sub-committees or clusters. A cluster is a method of organization in which specific individuals or groups come together to work on common tasks or interests within the spokescouncil or larger action. For example, during a mass demonstration, there could be a direct action cluster that is responsible for blockading a road, a performance art cluster that creates and performs street theatre, or a medical cluster that sets up first aid stations and organizes roving medics to provide first aid for demonstrators. Clusters can also be organized around affinity groups' locations of origin (i.e. an Ottawa cluster) or an issue or identity (i.e. student cluster or anti-sweatshop cluster), among others. While clustering

friends, but in the 1920s it became the basic organizational unit of the Spanish anarchist confederation, Federación Anarquista lbérica (FAl) (Graeber 2009: 288).

${ }^{12}$ Affinity groups may also send two spokes to a meeting: one presenting the viewpoints and proposals of their group, and the other taking notes. 
is practical in terms of making the process more manageable, it is also believed to be strongly democratic as it encourages autonomy and decentralization in order to make decisions at the most "local level as possible."

\section{Neo-Federalism within the Politics of Becoming}

What makes spokescouncils unique is that they exhibit the decentralized networking logic that is envisioned by contemporary anarchists. The organization of mass direct actions via spokescouncils allows activists to challenge the major institutions and symbols of domination, while simultaneously prefiguring "emerging [anarchic based] models of organization" (Juris, 2008: 126). The significance is that the assembly prefigures a model for macro-organizing broader networks and social relations. For activists, the chance to mobilize around a global summit and having hundreds of people horizontally working together in a democratic manner allows the participant to embody and experience a possible society that functions along the lines of their ethics (Maeckelbergh, 2009: 96). One activist writes:

"For me, it's not so important what happens at the summit, but more what we create, how we organize. [Our decision-making practices] will become a model of how we want to organize our world ourselves, a new way of working together...[The Dissent!] network was about anti-capitalism, antistate and about taking control of our own lives and creating alternatives" (cited in Maeckelbergh, 2009: 96).

Prefiguration, then, is understood to be distinct from both consequentialist and deontological ethical approaches. The former declares that only the end, the consequences of an act matter, whereas the latter privileges the means over the ends. Anarchist prefiguration, however, is aimed at the conflation of both means and ends with the desire to render them indistinguishable (Franks, 2003: 13; see also Maeckelbergh, 
2009: 88). Thus, participants act according to their own values when organizing actions against systems of domination, which simultaneously provides and embodies the desired visions of a future society. This does not mean a complete rejection of consequences per $s e$, but rather that participants assume the ends and means to be interconnected, "where the means are the result of the past ends and results in future ends", and therefore participants reject "a focus on either means or ends to the exclusion of the other" (Maeckelbergh, 2009: 88-89).

Organizing mass direct actions via spokescouncils, therefore, illustrate performative terrains where anarchic macro-politics are physically embodied. Consider the mass direct action in Seattle of 1999. The building where the World Trade Organization (WTO) meeting was to be held was effectively barricaded by activists, thus preventing WTO delegates from gathering. Anarchist activist Starhawk describes the methods used by the Direct Action Network (DAN-Seattle):

"Each group was empowered to make its own decisions around how it would participate in the blockade... [These] groups were organized into clusters. The area around the Convention Centre [where the WTO meeting was held] was broken down into thirteen sections, and affinity groups and clusters were committed to hold particular sections. As well, some groups were "flying squads" - free to move to wherever they were most needed. All of this was coordinated at spokescouncil meetings...In practice, this form of organization meant that groups could move and react with great flexibility during the blockade... No centralized leader could have coordinated the scene in the midst of the chaos, and none was needed - the organic, autonomous organization we had proved far more powerful and effective (Starhawk, 2002: 17-18).

These tactics depict the effect forging of macro-horizontal organization and collective will, which form across diverse and other conflicting protest groups. By deploying subversive yet prefigurative tactics, they attempt to disrupt symbols and institutions of domination, while demonstrating that other forms of life are, indeed, 
possible (Critchley, 2007: 124). Starhawk's 'possible' vision, for example, alludes to a hypothetical anarchist future, in which a "Seattle" spokescouncil can be formed to organize across the greater terrain, and the spokes that participate in them could be democratically empowered and rotated from their local neighborhood assemblies. Within those neighborhoods, there might also be spokes from more specific institutions or organizations, for example, a spoke that coordinates for the healthcare workers from a local clinic or hospital, or a spoke that coordinates for local transportation workers from a particular union, or a spoke that organizes and provides public services in that particular neighborhood. These local spokes would then form sub-committees (clusters) to coordinate actions or decisions that are more issue specific like a 'medical' cluster where various spokes coordinate for local healthcare workers or a 'transportation' cluster where spokes who coordinate for local bus drivers or subway operators could organize to facilitate decisions beyond their terrain.

\section{Towards a Post-Utopian Federalism}

One can see that the prefiguration of spokescouncil assemblies closely resembles Bakunin's federalism. Both Bakunin's vision, and the organizational structure of spokescouncils, for instance, works under the premise that decision-making must be as close as possible to those who are directly concerned. In order for this to properly function, decentralized decision-making must be embodied not only at the spokescouncil or federalist level, but it must also entail a material decentralization of infrastructure so that smaller territorial areas, be it regions, municipalities or neighborhoods, can enjoy "considerable functional independence as material guarantee of their political autonomy" 
(Cohn, 2006: 211). The difference between the two, however, is that the Bakunin's federalism is intended to become a permanent, rigid structure while the spokescouncils are temporary and fluid, only forming if and when organization necessitates mass participation. As one activist explains:

"We have come from many different sectors to organize things in a different way: assembly based, plural, and diverse. At the end of the twentieth century, political structures are becoming more participatory. We are a movement of movements, where everyone has as pace. We can't have a rigid structure or rigid manifesto. Rather, we have to create space to bring to gather the maximum number of people according to some basic common principles, and each collective should work autonomously. We should not become homogenizing structure. We have a series of coordinating tools and we can continue coming together when we have things to discuss (cited in Juris, 2008: 110).

In Chapter One, I demonstrated that today's anarchists reject a hegemonic politics because it is perceived as a dangerous practice. While anarchists continue to speak of bringing about major social changes, (which can be understood as revolution in the general sense) they do not speak of a revolutionary moment. As another activist writes:

"We don't need some completely overarching revolutionary strategy... [Spokescouncils are] not THE network of resistance, we shouldn't be trying to involve everyone possible, or we monopolize everything. I don't see [our assembly] as some kind of revolutionary council. We should get back to begin what we already are, a network" (cited in Maeckelbergh, 2009: 112).

Spokescouncils, therefore, are not spaces where revolutionary moments are invoked; participants do not plan strategic goals of 'smashing' capitalism or the State within a linear timeframe, while simultaneously influencing others to do so. Nor are they spaces where a singular essentializing political identity is established; an individual who participates in an assembly does not become a "member." Rather, the organization of direct actions via spokescouncils allow for a multitude of singularities to subvert and disrupt the existing State-capitalist order, while opening space for prefiguring new radical 
alternatives. This space allows actors to experiment with new models, where diverse political goals, imagined alternatives, and revolutionary subjects are "living, changing entitles because they are repeatedly brought to life each time in a different form" (Maeckelbergh, 2009: 98). Rather than recruiting 'anarchists', the objective is horizontal expansion and connectivity among diverse movements, 'within flexible and decentralized information structures that allow for maximal coordination and communication' (Gordon, 2008: 18). It is in this sense that the spokescouncil model parallels Derrida's notion of différance; the differences between diverse groups are understood as strands of a network that can be woven together to create a multitude of singularities and not as oppositions in which the 'best' one need be determined to the elimination of all others (see Derrida, $1994 ; 1982)$.

\section{Singularities, Différance, $\&$ the New International}

In Specters of Marx, Derrida discusses the possibilities of a democracy that can transcend the limitations of radical politics by desiring a political alliance that could form 'without organization, without nation, without state, without property'; an alliance that he called a new International (see Derrida, 1994). Derrida believed this new International would barely be considered a community, as it would "function" through a politics of différance. As briefly noted in the previous chapter, Derrida discusses a strategy of différance with an " $a$ " to signify a movement of differences where identity is always unstable and never absolute. For Derrida, différance does not constitute itself as an essential identity of difference; instead, it remains open to contingency, thereby undermining fixed identities and allowing actors to move beyond the limitations of 
essentialism. As Derrida notes, différance "governs nothing, reigns over nothing, nowhere exercises any authority... Not only is there no kingdom of difference, but difference instigates the subversion of every kingdom" (1982: 22). However, this series of differences is not without a 'structure'. Rather, it could be understood as 'infrastructure': a network that functions as a weave, or an unordered combination of differences and antagonisms. The very nature of this network is that of a "non-system": the differences that constitute it are not dissolved by the infrastructure. It does not have a stable, singular identity as no ordering principle or authority governs it. This does not mean that identity is abolished but rather, it is a "place" that eschews essence, authority, and centrality. As Derrida contends:

"There is no essence of the difference; not only can it not allow itself to be taken up into the as such of its name or its appearing, but it threatens the authority of the as such in general, the thing's presence in its essence" (1973: 158).

On this account, this new International would not be a network of "international communist parties.' Nor would it be a formal anarchic federation that Bakunin had envisioned. Instead, it would consist of an alliance of scattered friends. This alliance would lack formal membership and fixed political boundaries, and it would be open to all without exclusion. In other words, it would be democratic politics that cultivates the singularity of every Other, and which powerfully resists ethnic or national homogeneity and identitarian emotions (Derrida, 1994; see also Glendinning, 2011).

\section{Spokescouncils as possibilities of non-hegemonic Macro-Organization}

A spokescouncil similarly exhibits Derrida's desire for a New International, and notion of difference and singularities, as they are an example of an infrastructure that 
lacks formal memberships, fixed boundaries, and a centralized authority. As noted above, it is a space where a series of different actors and affinity groups coordinate actions together without governing or reigning over each other.

Most assemblies begin by formulating a set of guiding principles and hallmarks as a frame of reference for participants to identify commonalities. The principles also act as a tool for resolving disputes without becoming a set of essentializing membership rules. During the 2010 anti-G8/20 demonstrations in Toronto, The Toronto Community

Mobilization Network (TCMN), for instance, adopted the following mandate:

"1. Our solidarity is based on respect for a political diversity within the struggle for social-justice. As individuals and groups we may choose to engage in a diversity of tactics and plans of action but are committed to treating each other with respect;

2. We realize that debates and honest criticisms are necessary for political clarification and growth in our movements. But we also realize that our detractors will work to divide us by inflaming and magnifying our tactical, strategic, personal and political disagreements. For the purposes of political clarity, and mutual respect, we will speak to our own political motivations and tactical choices and allow other groups and individuals to speak on their own behalf...

3. As we plan our actions and tactics, we will take care to maintain appropriate separations of time and space between divergent tactics [emphasis added]. We will commit to respecting each other's organizing space and the tone and tactics they wish to utilize in that space. We will commit to clearly communicating our choices of tactics wherever possible;

4. We oppose any state repression of dissent, including surveillance, infiltration, disruption and violence. We agree not to assist law enforcement actions against activists and others. We oppose proposals designed to cage protests into high-restricted "free speech" zones, and we will support all those arrested..."

These hallmarks deliberately avoid referring to any specific political ideology, such as anarchism, leaving the principles structurally open so as to maintain solidarity between anti-authoritarian anarchists, communists, environmentalists, Indigenous groups, labour 
unions, NGOs, among others. Given the broad diversity of political identities, the guiding principles were not intended to be membership rules, but simply a tool that would help aide with disagreements. For example, during the TCMN meetings, if there were heated debate on the use of 'confrontational' tactics such as property sabotage, participants could always refer back to the first and third guiding principle, which clearly outlines that the council had initially agreed to a diversity of tactics. Accepting a diversity of tactics did not mean that every participant or group had to endorse, participate or be held responsible for all tactics that were used, and therefore there was space for antagonism and conflict. This is further clarified in the TCMN mission statement, which illustrates:

"... if we are to truly build a socially just world, it will take many different tactics much creativity and many different approaches. It is this that allows us to work together even when we disagree."

As we can see, conflict is seen as inevitable, even positive and necessary, to ensure that no singular multitude reigns. In fact, if one group strongly rejected another group's ethics, principles, or actions, they were free to abstain from those actions, undertake opposing actions outside of the spokescouncil, or completely disassociate. This is further illustrated in the TCMN mission statement:

"We work together in solidarity and respect. This does not mean we endorse everything each of us does, or that we agree on all things. But we will listen to each other, we will discuss our differences openly and honestly, where necessary, we will agree to disagree and we will support each other when attacked."

In other words, participants and groups within the TCMN were not forced to change their own organizational structures and adapt a singular 'anarchistic' one. Nor was there any requirement to agree to the same set of desired goals and tactics. Indeed, one could argue that the organizational principles behind TCMN and other 
spokescouncils are anarchistic, and a large number of participants may be identified as anarchists. However, the assumption was that as long a group was willing to organize through anarchistic principles, their long-term vision, their desired goals, and how they choose to organize their own organization or community in the future, was their choice.

One can see that the concept behind a spokescouncil assembly is to allow participants to freely share ideas and resources without being bound by labels. The desire is to allow participants to encounter multiple singularities, while each singularity is free to organize according to their own values and ethics. It is in this sense, then, that the spokescouncil model can open the doors to a possible post-utopian "macro" organizational structure within "an endless variety of communities, associations, networks, and projects overlapping and intersecting in every way possible" (Graeber, 2004: 40). However, one can unmask two difficulties with spokescouncil's

\section{The Paradox and Limitations behind Spokescouncils}

First, while spokescouncils are intended to be spaces that allow for diverse singularities to flow, clearly not all diversities are acceptable. Most singularities hail mainly from the same "left" side of the political spectrum, and even then, not all leftwing milieus are given solidarity and mutual aid; many groups continue to be excluded depending on the context, location, and intent of the particular spokescouncil. Consider, for example, the hallmarks put forth by the Peoples Global Action (PGA):

"1. A very clear rejection of capitalism, imperialism and feudalism; all trade agreements, institutions and governments that promote destructive globalisation;

2. We reject all forms and systems of domination and discrimination including, but not limited to, patriarchy, racism and religious fundamentalism of all creeds. We embrace the full dignity of all human beings. 
3. A confrontational attitude, since we do not think that lobbying can have a major impact in such biased and undemocratic organisations, in which transnational capital is the only real policy-maker;

4. A call to direct action and civil disobedience, support for social movements' struggles, advocating forms of resistance which maximize respect for life and oppressed peoples' rights, as well as the construction of local alternatives to global capitalism;

5. An organisational philosophy based on decentralisation and autonomy."

The third hallmark demonstrates that the PGA explicitly distances itself from any NGO or advocacy group that operates to change the World Trade Organization, despite the fact those groups may be 'left' leaning and may also share similar ethical principles as other PGA organizers. The fifth hallmark can similarly be understood to exclude the centralized and hierarchical organizational methods of the authoritarian left; groups that, like anarchists, want to overcome the matrix of domination but see its possibility only through hierarchical organization and State control. On this account, a set of 'anarchic' norms is still perpetuated and, thus, there remains a risk that is paradoxically essentialist in nature. The anarchic Invisible Committee, which remains skeptical of the post-utopian possibilities of any assembly structure, makes this critique clearer:

"An assembly is not a place for decisions but for palaver, for free speech exercised without a goal... It's not a matter of critiquing assemblies or abandoning them, but of liberating the speech, gestures, and interplay of beings that take place within them. We just have to see that each person comes to an assembly not only with a point of view or a motion, but with desires, attachments, capacities, forces, sadnesses and a certain disposition toward others, an openness. If we manage to set aside the fantasy of the General Assembly and replace it with an assembly of presences, if we manage to foil the constantly renewed temptation of hegemony, if we stop making the decision our final aim, then there is a chance for a kind of massification, one of those moments of collective crystallization where a decision suddenly takes hold of beings, completely or only in part..." (2009: 122-123).

For the Invisible Committee, any assembly structure must not only be temporary so as to avoid essentialization, but the space should, in fact, avoid constructing any codified 
norms whatsoever, including guiding principles and hallmarks. The committee reminds the reader that assemblies should only be a space reserved for communication and logistical coordination, rather than producing norms. As the committee further contends:

"There's no ideal form of action. What's essential is that action assume a certain form, that it give rise to a form instead of having one imposed on it. This presupposes a shared political and geographical position-like the sections of the Paris Commune during the French Revolution - as well as the circulation of a shared knowledge. As for deciding on actions, the principle could be as follows: each person should do their own reconnaissance, the information would then be put together, and the decision will occur to us rather than being made by us. The circulation of knowledge cancels hierarchy; it equalizes by raising up. Proliferating horizontal communication is also the best form of coordination among different communes [affinity groups], the best way to put an end to hegemony" (2009: 123).

As we can see, the Committee's analysis suggests that spokescouncils have still yet to transcend the limitations of essentialism, counter-hegemony, and identity politics.

While the collective is correct in that to overcome these limitations, it would require the complete eradication of all codified norms, the argument, however, exposes a second difficulty: how could macro-organization run efficiently without some basic set of guiding principles? In a future anarchist society, what if a horizontal community had to co-ordinate subway lines or access to hospitals with another community that did not, for example, explicitly reject sexism or racism, and, on the contrary, maintained white supremacy and patriarchy? What if it were difficult to dissociate from them? Prefigurative spokescouncil organization assumes that subjects would be living in a 'borderless' world. Assuming that autonomous regions would organize around spokescouncils, would the assemblies allow neighboring political representatives of nation-States to partake? Ultimately, spokescouncils, in their current form, do not sufficiently address these complex realities 'on the ground.' 
To be clear, I am not suggesting that spokescouncils cannot work in "the real world," but rather, that difficulties continue to persist, and that they need to be adequately addressed in order to strengthen anarchy as yet-to-come. Nonetheless, despite its limitations, what cannot be denied is that concepts such as decentralization and autonomy are not just abstract values; they are clearly being practiced and experimented with by activists. While macro-organization has yet to transcend essentialist and hegemonic norms, the organization of spokescouncils open the doors to its possibilities.

\section{II. "MICRO" ORGANIZATION}

While network style organizing expresses the movement(s)'s architecture on a macro level, most anarchist organizing takes place on the 'micro' level. The most common form takes shape in the affinity group model (see Gordon, 2008: 15). As discussed in the first half of this chapter, a large number participants within spokescouncils organize around affinity groups, which activists believe to be the 'elementary particle of voluntary association' (Graeber, 2009: 288). This raises a number of questions: How could a local community or neighbourhood be organized? What type of decision-making procedure can be used? How can they transcend law's violence? To answer these questions, many activists consider the affinity group model as a possible vision not just for micro-organization, but its very existence is believed to offer a form of productive or constructive direct action. What is unique about the affinity group structure is that those involved also commonly utilize a consensus-oriented decision-making process. Anarchists believe consensus decision-making prefigures a process that attempts to transcend law's violence. Yet, it poses a paradox as consensus decision-making in its 
current form not only continues to be contradictory in its procedures, but it is also largely limited by its inability to completely abandon humanist assumptions.

\section{What is an Affinity Group?}

An affinity group is a small group of people (roughly six to twenty) who build strong relationships of trust and friendship with each other and invoke direct action together through a horizontal structure — without hierarchies and formal leadership structures such as executives, representatives, and/or presidents. Affinity groups can also be labelled as action groups, as many groups are ad hoc and fleeting, forming shortly before a major action and dissolving immediately after. As noted above, affinity groups often form temporarily to participate in spokescouncils during mass mobilizations. However, affinity groups can also be larger, and work together for many years on several different projects or actions. In this context of a more "permanent" group, the term collective or cooperative can be used (Maeckelbergh, 2009: 43-44; see also Gordon, 2008: 15-18).

The difference is that anarchist collectives have informal face-to-face "memberships" and not only form for building resistance against institutions of domination, but to also construct practical alternatives to them "on the ground." In other words, many affinity groups engage in what some scholars call a form of productive direct action. This can include providing services for victims of sexual assault and violence without police intervention (Philly Stands Up!, Incite!); writing for an anarchist publication or an alternative media project (CrimethINC, Common Cause, Indymedia); operating an agricultural commune or bike co-operative; or providing free vegan street- 
kitchens or political literature to prisoners (Food Not Bombs!, Black Cross), among others.

\section{Affinity Models within the Politics of Becoming}

The affinity group model, therefore, embodies and prefigures a possible vision for a post-utopian 'micro' social organization, such as a small "autonomist" community or neighbourhood. In addition, they also act as an 'outside' alternative on the 'inside', which is believed to disrupt and subvert the State and Capitalism's attempt to 'set itself up or erect itself into a whole? (Critchley, 2007: 1.22). In other words, affinity groups experiment with the temporary 'autonomist spaces' that I discussed in the previous chapter. One activist who organizes with the Vancouver Independent Media Centre (IMC) expresses this:

"Independent Media Centre is, I think, one of the most important recent examples where grassroots movements, particularly those in the North, work to create spaces that are autonomous from capital and the state, where processes unfold according to logics dramatically opposed to the instrumentalist logics of accumulation and centralized decision making, even while these movements use technologies created for these purposes. It is also an instance of a subtle shift in political activism and struggle, a move from strategies of demand and representation to strategies of direct action and participation" (cited in Day, 2005: 39).

By creating alternative sources of information, IMC's objective is to combat corporate concentration in media ownership. In doing so, activists are empowered to participate directly in the 'negation and reconstruction of mass-mediated realities.' As an example, IMCs are structured with independent centres in various different cities. Each centre is not only independent from the "corporate world," but they are also independent from one other. In other words, there is no centralized hub that disseminates a particular 
editorial line, and in fact, on some of IMC websites, there are no editorial lines at all. The idea is that the interests and resources of the local communities the IMC serves drive each centre, and thus, IMCs build a high degree of differentiation into the "system" at its most basic level. The value behind the affinity group model, then, is not necessarily because of its political or organizational efficacy, but in building alternative subjectivities and "ways of being" within the existing hegemonic order (Day, 2005: 35). The Invisible Committee similarly argues this point by claiming that the affinity group model not only serves as a possible vision for alternative ways of being, but that the very existence of an affinity group plays an important role in subverting the State-form, and therefore, opening space for alternative experimentation:

"The territorial question isn't the same for us as it is for the state. For us it's not about possessing territory. Rather, it's a matter of increasing the density of the communes, of circulation, and of solidarities to the point that the territory becomes unreadable, opaque to all authority. We don't want to occupy the territory; we want to be the territory... [...]... Every [affinity group] practice brings a territory into existence - a dealing territory, or a hunting territory; a territory of child's play, of lovers, of a riot; a territory of farmers, ornithologists, or flaneurs. The rule is simple: the more territories there are superimposed on a given zone, the more circulation there is between them, the harder it will be for [State-capitalist] power to get a handle on them. Bistros, print shops, sports facilities, wastelands, secondhand book stalls, building rooftops, improvised street markets, kebab shops and garages can all easily be used for purposes other than their official ones if enough complicities come together in them. Local self-organization superimposes its own geography over the state cartography, scrambling and blurring it: it produces its own secession" (2009: 109-109).

For the Invisible Committee, the organization of direct action via affinity group structures should not seek to mirror the archaic sovereignty or power structures it seeks undermine. In other words, affinity practices and prefiguration should not desire to be constructed as the new hegemonic principle of political organization, but instead, to remain the "negation of totality" as opposed to the "affinity of a new totality." The intent 
of these alternatives is thus to create space through an interstitial distance within the State. It is imagined that by continuing to ward off the matrix of domination, including both the State-form and capitalism, a cluster of affinity groups can not only "replace" dominating institutions, but they also resist the establishment of any order from above (Critchley, 2007: 122). It is in this sense, then, that contemporary anarchists are continuing the traditional anarchist project, while attempting to transcend its previously essentialist limitations by engaging in a politics of revolution yet-to-come.

Let us recall chapter one, in which I noted that contemporary anarchists continue a project similar to Kropotkin's vision. One can see, for example, that the ethical commitments and structures behind affinity group models are similar to Kropotkin's anarcho-communism and autogestion (worker self-management). Kropotkin believed that a future anarchist society should operate under horizontal principles, and the communist dictum 'to each according to his need to each according to their ability.' Participants within affinity groups similarly prefigure sharing tasks and skills, while designating temporary and informal roles amongst each other that are frequently rotated in order to ensure that hierarchies do not emerge. For anarchists, this circulation of roles and tasks is believed to empower participants because it embodies organizational, technological, and interpersonal skills that foster relationships of solidarity and mutual aid, while simultaneously subverting hierarchy and the concentration of power (Crimethinc, 2006: 18).

Kropotkin also argued that workers needed to develop alternative systems, such as worker controlled factories and other horizontally aligned associations of "free, selfdetermining human beings" within the existing body of capitalism and the State prior to 
any future revolution. By building these alternatives, Kropotkin believed space would be opened to allow for autonomist alternatives to both replace the State and capitalism and also aid in destroying them in order to emancipate the human subject from the matrix of domination. The assumption behind affinity groups is similar. As noted above, it is hoped that by building alternatives that can help provide services for everyday life, be it alternative media, food co-operatives, or even alternative dispute resolutions, affinity groups not only highlight the possibilities of alternative ways of being, but can also allow activists to disengage from the State and capital, however temporarily, with the hopes of eventually rendering them obsolete.

In light of post-structuralist critique, however, contemporary anarchists have begun abandoning Kropotkin's humanist and essentializing assumptions. As discussed throughout Chapter One, the former are not anticipating a future revolution in which the human subject will be emancipated. Nor are participants within affinity groups 'recruiting' subjects to become anarchists to advance a programmatic revolutionary project. One crucial difference between anarchists today and those of the past is that the former believe that the will of the majority, even through direct participation, is never justified in superseding the concerns of the minority. In other words, any system of majority voting is perceived as inevitably violent in the Derridean sense, whether or not the structure is egalitarian and horizontal. As I will show, anarchist scholar and activist Uri Gordon, who argues that at some point, existing democratic discourse always assumes that the political process results in collectively binding decisions, unpacks this. 


\section{Towards a Law of Anti-Laws: The Consensus Process}

Paralleling Derrida's critique of violence, Gordon notes that even decisions that are a result of a free and open debate by all those affected (as advocated by traditional anarchists) do not change the fact that outcomes are binding. Collectively binding decisions made by the majority requires enforcement, and this enforcement will inevitably require some permanent body of exercising coercion, even in a decentralized manner. Unless this enforcement is somehow voluntary and consensual, Gordon argues that it contradicts the nature of anarchic politics and risks falling into an authoritarian trap (Gordon, 2008: 67-68). What, then, do anarchists perceive as a possibility for a decisionmaking model that can transcend this violence? If not all participants within affinity groups identify as anarchists, then how can a diversity of perspectives be respected without enforcement and coercion?

In order to address the problems of hegemonic coercion, affinity groups commonly utilize what is known as a consensus decision-making process. Instead of voting proposals through or down, proposals are worked and reworked, or reinvented until everyone consents to them. The idea is that instead of allowing the majority to determine the final outcome, every participant, including a dissenting minority, must arrive at a collective decision. As I will elaborate, consensus mechanisms such as reservations, stand asides, and blocks are believed to increase the likelihood that a collective decision will be voluntarily carried out by those who make it, thus highlighting the possibilities of a decision-making practice that can transcend the violence of law (Gordon, 2008: 70; see also Graeber 2009). While this model attempts to move beyond the violence of law, this practice also paradoxically exposes that anarchists have not been 
able to completely transcend procedural contradictions given the 'extra-judicial' notion of supermajority and modified consensus. Moreover, consensus continues to be largely limited by humanist assumptions, as it tends to minimize the possibilities of unacknowledged/unconscious forms of repressive power and domination.

In contrast to voting on a final decision as in traditional democratic models a facilitator tests for consensus by asking if there are any blocks, friendly amendments, or stand asides (also known as reservations) within a consensus-oriented affinity group. ${ }^{13}$ In general, affinity group meetings start with an agenda of what to discuss, after which discussion proposals are made. A proposal is the suggestion of a course of action that an attendee or delegate presents at a meeting. While bringing proposals in writing is encouraged, most proposals are almost never written down in a codified form. They are, however, recorded by a notetaker or scribe. Proposals do not always have to refer to a particular course of action. For example, proposals can request the modification of the guiding principles of a group. After a proposal is presented, the first task of the facilitator is to ask for clarifying questions. The facilitator can then ask if there are any concerns: what are the possible problems such a course of action might cause, reasons why it might not be the best course of action, and so on. At this point, it may become obvious that there are strong feelings against the proposal, and the person who presented it may decide to withdraw it. Alternately, attendees may propose one or more friendly amendments to address the concerns that - if the person making the proposals accepts - then becomes part of the proposal (Graeber 2009: 307-317; see also Maeckelbergh, 2009).

\footnotetext{
${ }^{13}$ Consensus-oriented groups commonly use hand signals. For example, (1) I agree: thumbs up, or twinkling fingers in the air upwards; (2) I have reservations, or disagreements: thumb sideways, or twinkling fingers in the air downwards; (3) I am blocking: thumbs down, making a fist, or crossing arms in an $\mathrm{X}$.
} 
Finally, after going through the process, the facilitator asks if there are any stand asides or blocks. Stand asides mean that a participant will not accept a proposal or course of action either because s/he has concerns or disagrees with it. The concerns, however, are not serious enough for the objector to block and veto the proposal. Stand asides reinforce the anarchist principle of voluntary association, in which individuals are not obliged to follow a collective decision: an individual can give their consent to others to act upon the decision, even though the person standing aside does not agree with it and chooses to abstain. The scribe, however, registers the individual's dissent, and it would be clearly stated that they would not help implement the proposal. A stand aside means "I personally cannot do this, but I will not stop others from doing it", thus, making the person who stood aside not responsible for the consequences of the proposal or decided course of action (Trapese Collective, 2007: 66; see also Graeber, 2009).

Perhaps the most crucial aspect of consensus decision-making is that every participant has the opportunity to block a proposal or a course of action. Blocks differ from stand asides in that they act as a veto and have the potential to prevent consensus from being reached. According to anarchists, blocks are only supposed to be used when a participant believes a proposal or a course of action violates the fundamental principles of the organization. However, it is argued that blocks rarely occur because substantial problems are typically addressed before a proposal takes shape in its final form. In her ethnographic study of affinity groups, Marianne Maeckelbergh notes that obstacles and blocks are uncommon because dissenting opinions often change the minds of members once the group weighs the merits of each differing point of view:

"Blocks are an important part of the democratic process and crucial to keeping it inclusive, but I have never seen them actually accepted. Usually 
what happens in practice is that the blocker gets a chance to explain his or her particular concerns and the group agrees to make adjustments to the proposal taking these into consideration, or the group may decide to split and take two or more courses of action" (2009:51)

In other words, the process is designed so that most concerns are debated and 'solved' prior to the implementation of the decision. A resolution for certain conflicts is not always believed to be necessary; on the contrary, it could even be hegemonic. ${ }^{14}$ Like the spokescouncil format, the consensus process is perceived to allow space for antagonisms and unresolved conflicts. The assumption is that the "desires and interests" of participants separated by space will be diverse and manifold, in need of "coordination" rather than unification. The significance is the belief of anarchists that consensus decision-making opens up the possibility of social diversity "being translated into a diversity of [non-hegemonic] outcomes", although, it must be noted that this process is not necessarily a smooth one (Maeckelbergh, 2009: 102; Cohn, 2006; 209).

On very rare occasions, however, blocks can also be serious enough to put a group in "crisis." When someone is unwilling to respect the veto, it becomes a difficult situation in which the group must decide whether the proposal has enough significance to jeopardize the group. While it is important to note here that most affinity groups do not use formalized consensus procedures, some larger groups tend to use the following as back-up options:

(1) One backup option often utilized is to agree to disagree by not coming to an agreement on the issue, and asking whether the proposal or outcome will still be needed

\footnotetext{
${ }^{14}$ In her studies, Maeckelbergh finds that: "Whenever it is possible to resolve a conflict through creative means that do not result in one position winning at the expensive of the other, the resolution of [that] conflict is certainly encouraged, but at limes this type of resolution is neither possible nor necessary" (Maeckelbergh, 2009: 102).
} 
in six months, a year, or five years. (2) A second option is to put it on hold by coming back to it at a later meeting. This allows the chance for the re-evaluation of the proposal in order to come to a different perspective. If the group is at an impasse, then there is a third option: (3) modified consensus: If there are only one or two blocks, but other participants strongly feel it is absolutely crucial to come to a decision, there may be options such as "supermajority", or consensus minus one, two, or three. Anarchists concede that modified consensus is undesirable and can contradict the very principles of classical consensus. They indicate that a group would only rely on it if were voluntarily agreed upon in their guiding principles or group agreement, and if everything possible had been done to achieve consensus (Graeber 2009: 307-317; see also Maeckelbergh, 2009).

The Trap: Paradoxes, Contradictions, and Limitations behind Consensus

While techniques such as reservations and stand asides indicate that anarchists are attempting to transcend law's violence, the difficulty is that groups who use modified consensus or a supermajority fall into the same trap. Who decides what constitutes an 'emergency" proposal? If a majority decides it, then does this not violate the very essence behind the consensus model itself? This particular question is largely unanswered by anarchist scholars who advocate for some form of modified consensus, and it only reveals that it continues to be "dull and [problematically] procedural as the [liberal] parliamentarianism that it opposes" (Critchley, 2007: 127).

In order to overcome this limitation, some anarchists have called for an informal consensus: a consensus without procedural norms. Like their criticism of spokescouncils 
discussed earlier, the Invisible Committee also believes that all formalized procedures at the micro-level should be abandoned:

"The need to assemble is as constant among humans as the necessity of making decisions is rare. Assembling corresponds to the joy of feeling a common power. Decisions are vital only in emergency situations, where the exercise of democracy is already compromised [my emphasis]. The rest of the time, "the democratic character of decision making" is only a problem for the fanatics of process" (2009: 122).

According to the Committee, anarchists are fixated on procedural mechanisms, which are problematically rooted in unquestioned and simply liberal concepts of freedom and autonomy. Instead, the Committee calls for what Simon Critchley terms as dissensus, where decisions 'come to participants rather than being made by them' (the Invisible Committee, 2010), while constitutive dissensual antagonisms of political life continuously call into question any form of sovereignty that maintains "order, pacification, and security", including those of the formalized consensus process (Critchley, 2007: 129).

Yet, the argument that decisions should 'not be the final aim' does not consider certain 'on the ground' challenges. Consider, for instance, that a majority in a future anarchic community wants to build a railroad within a residential area. The community believes that this railroad is crucial for its livelihood, as it allows for the ability to trade goods and resources with other communities in a more efficient manner. However, building it in a residential area means that the trains will be an inconvenience to the neighbourhood, as it will be often loud and disruptive. What if an individual who resides in one of these homes and participates in a local assembly was not persuaded by other members to consent in building it? What if, in a more formalized assembly, rather than standing aside, the individual actively blocked all proposals that would allow for some 
compromise? How could a community, in this situation, move beyond this impasse without resorting to some degree of coercion? What this suggests is that those who advocate for consensus decision-making, including those who argue that structural norms should be abolished, have not completely abandoned their humanist assumptions. If decisions are going to 'come to participants,' rather than being made by them, it rests on a notion human beings are 'rational' or capable of moving beyond impasses, even if it means that conflicts will not always be solved.

The inability to provide answers to the questions posed above indicates that consensus decision-making is still inadequate. Regardless of its structural formality, it reveals that today's anarchists have not completely abandoned nor transcended their humanist assumptions. To clarify, I am not suggesting that consensus seeking should be rejected. However, I believe anarchists may need to (re)-conceptualize the consensus process, and perhaps, even abandon it all together in search for something new; a process that can transcend hegemonic and humanist limitations.

\section{Concluding Remarks: Radical Possibilities as an Ongoing Process}

Throughout this Chapter, I have discussed, analyzed, and critiqued contemporary anarchistic prefiguration. My contention was that prefigurative practices not only act as protest tools with which to subvert systems of domination, but that the very organization of these practices also highlights possibilities and visions of a of post-utopian decision making and social organizational model. More specifically, the most crucial question I posed at the beginning of this chapter was: how do anarchists organize? To answer this question, I explored two modes of anarchist organization: macro, and micro. In the 
former, we have seen that anarchists offer the spokescouncil format as an alternative to the State-form, where a multitude of singularities can coordinate actions and decisions without ever conforming to a hegemonic singularity. This, I believe, not only parallels Derrida's ideal of a New International, but the informal and fluid structure of spokescouncils also attempts to transcend the limitations of classical anarchistic federalism. This practice, however, continues to be limited by its paradoxical inability to transcend essentialist norms.

In the second half of the chapter, I explored 'micro-decision' making, where I analyzed the affinity group and consensus decision-making models. My contention was that the affinity group model not only serves as a possible alternative to smaller communal structures, but that their very organization constitutes a form of productive direct action. In other words, because some affinity groups and collectives form to provide alternative services, they illustrate the temporary creation of 'alternative spaces' of an outside on the inside of the dominant hegemonic order. Moreover, one crucial aspect of affinity group models is also their commitment to utilizing consensus decisionmaking. With procedural concepts such as reservations and stand asides, the consensus model attempts to transcend the violence of law. Despite the honourable intentions behind consensus, however, it is largely limited due to its procedural contradictions and humanist assumptions.

Perhaps organizational models such as spokescouncils, affinity groups, and consensus decision-making are only plausible in the "thin air of dislocated network politics", given that such models have been "untested in the more messy ground of community living, food production, etc" (Gordon, 2008: 69) My objective throughout 
this chapter, however, was not to concretely answer whether these models can or cannot work in a future anarchistic society or whether they are applicable to all aspects of social life. Instead, my task was to explore their possibilities, to consider their merits, and to unmask their limitations. By doing so, my intent was to consider alternative ways of life and being that can perhaps open doors to transcend hegemony and institutional violence while also contributing to a growing body of knowledge that explores these alternative possibilities.

Nonetheless, most anarchists accept that, at this point in time, to completely wither the State-form and the various systems of domination is a difficult and daunting task (see Critchley, 2007). Practicing prefiguration may contribute to a politics of becoming and it may build alternatives of an outside on the inside. These alternatives, however, do not guarantee that a fundamental social transformation will ever occur or that such models are sustainable in the long term. Despite the collapse of macro and micro power, as discussed in Chapter One, the inevitable reality is that the structure of macro-domination - Capitalism, the State, and its various apparatuses - are forces that are self-protecting and, therefore, evolve in order to ensure the continuation of their existence. Some anarchists, therefore, believe that these structures must also be actively fought against and warded off through acts of militant resistance (see Day, 2005). But what does this resistance look like, and how can these tactics be utilized without falling into the trap of counter-hegemonic practices? In my final chapter, I explore these questions by analyzing Black Bloc tactics, which not only highlight the emergence of a new, insurrectionary resistance, but their organization also prefiguratively embodies postutopian aesthetics and epistemology. 


\section{CHAPTER 3 \\ BEHIND THE BLACK MASK}

"Get ready to blend in, to put it on and disappear [...] I could be anyone, anywhere $[\ldots]$ To have a brand new identity $[. .$.$] or to be no one at all this time [...] Just give$ me a black mask."

-The (International) Noise Conspiracy: Black Mask

In the preceding chapters, $I$ indicated there is an emergence of a new kind of anarchism, a post-utopian anarchism, where radical activists reject hegemonic politics in favour of a politics of becoming and a revolution yet-to-come. Contemporary anarchists not only desire this method of politics, but they also prefiguratively embody it into their organizational structures. Although they remain imperfect, models such as spokescouncil assemblies and consensus decision-making go beyond protest coordination by also acting as possible visions of alternative models for social organization. Yet mass demonstrations alone are believed to be insufficient in challenging the matrix of domination. Anarchists believe structures of 'macro' domination are forces that are self-protecting and evolving to ensure a continued presence. Thus, for many activists, mass direct actions without a militant fervor are not enough to threaten State and capitalist authorities. How, then, do some anarchists envision militant resistance in an era where power is decentralized and fluid? What sorts of tactics are believed to be appropriate for subverting institutions of domination?

One important facet of the anarchist milieu is encapsulated by the militant and violent actions of a group commonly referred to as the black bloc. As I argue below, black bloc tactics and its aesthetics- hurling stones and Molotov cocktails, building barricades, wearing face masks and all-black attire, street fighting with the police, and sabotaging corporate property, among others - has a dual effect. Externally, it symbolizes 
a desire for a decentered social transformation process. Internally, it allows activists to prefiguratively explore new forms of anti-authoritarian and anti-capitalist identities yetto-come. I believe this dual effect opens the doors to the possibilities of a militant postutopian resistance, one that attempts to transcend the limitations of counter-hegemonic practices, and essentialism. However, the formations of black blocs in their current form have yet to transcend essentialist and paradoxical limitations.

I begin the chapter with a discussion of the theoretical origins of black bloc tactics. In contrast to paramilitary-style violence, bloc activists call for resistance based on a notion of social insurgency that deliberately avoids physical mutilation. This approach is inspired by Foucault's critique of power and also his concept of social war. Given that Foucault did not engage in strategic discussions, however, I illustrate how bloc activists have drawn upon other scholars such as Giles Deleuze, Felix Guattari, and Guy Debord to fill this gap in Foucault's work. Concepts such as rhizomatic resistance, and subversive psychogeography, for instance, play a prominent role in the theoretical underpinning of bloc tactics.

The second section will examine the relationship between emancipation and black bloc violence. This will involve both an analysis of and comparison between Frantz Fanon's theory of revolutionary de-colonial violence, and black bloc tactics of sabotage. While the two share similarities, my contention is that the latter expresses a method of resistance that attempts to transcend the limitations of counter-hegemony, where subjects attempt to temporarily emancipate themselves from State-capitalist power, therefore allowing them to prefiguratively experience alternative ways of being.

The final section shall examine the relationship between the aesthetics of black 
bloc violence, and prefiguration of post-utopian subjectivity and identity. By utilizing Deleuze and Guattari's theory on face and subjectification, I argue that the aesthetics of black blocs-black masks, black clothes, black shoes - cannot be separated from its violence. By wearing masks and an all-black attire, it signals a desire among activists to move beyond identity politics, as the uniform allows subjects to prefiguratively experiment with new radical identities yet-to-come. However, it remains seemingly paradoxical, as the aesthetics do not fully escape the trap of essentialist subjectivity. Moreover, due to its inability to overcome this paradox, State forces continue to neutralize the formation of blocs in advance, thus exposing a severe limitation behind its radical potentialities.

\section{I. (SOCIAL) INSURRECTION \& POST-UTOPIAN RESISTANCE}

\section{What is a Black Bloc?}

A black bloc is not a formal political group or organization, but rather a "spontaneous" ad-hoc tactical formation where a leaderless affinity group and other individuals cluster together during large demonstrations to attack symbols of the State and Neoliberal Capitalism. By organizing through consensus decision-making and spokescouncil assembly models, bloc activities may include smashing windows or sabotaging governmental offices, large corporations, and/or financial institutions. Activities may also engage in "street fighting" with the police by throwing non-lethal projectiles or Molotov cocktails. While the primary purposes of bloc tactics are to cause economic damage and disrupt the normal functioning of (neoliberal) daily life, they are not limited to "offensive" attacks. Black Blocs may also form to express solidarity and to 
protect non-bloc protestors from police violence by acting as human shields (building barricades, standing before riot police lines), providing medical aid, and deliberately diverting riot police (misleading them or de- arresting protestors-rescuing them from arrest). They may also employ a repertoire of purely symbolic actions, such as spraypainting graffiti and burning flags. In addition to exerting militant protest tactics, black blocs have become notorious for their all-black aesthetic. Participants, for example, often wear black boots, black pants, black sneakers, black hooded sweatshirts, and black bandanas and/or ski masks. With their identities effectively hidden in uniformity, the main purpose is to avoid identification and surveillance from police film and video recordings. Masks and bandanas also provide further protection against tear gas and rubber bullets (Avery-Natale, 2010; Van Deusen, 2010; Shantz, 2009; Graeber, 2009).

The origins of black bloc tactics lie in the anti-State and antiCapitalist Autonomen (Autonomist) movement of West Germany, which initially developed at the tail end of the 1970s to defend squatters against evictions and antinuclear demonstrations from police attacks. Dubbed the "block bloc" by the media due to their heavy black clothing, ski masks, and helmets, autonomists were anarchist inspired activists whose discontent came not from the specific exploitation of their labour at their jobs, but from the "capitalist subsumption of their own daily life" (Trocchi, 2011: 310). In contrast to both Marxist-Leninist paramilitary organizations such as the Red Army Faction (RAF), and insurrectionary-anarchist groups that called for the violent destruction of the State, autonomists advanced a post-utopian politics of resistance that acknowledged State-capitalist power was no longer based on militarized domination, but primarily on the social relationships and hegemonic practices of daily life. As I shall 
elaborate below, this has led black bloc anarchists to resist the State and capital using non-lethal subversive techniques.

It was the protests against the World Trade Organization (WTO) of 1999 in Seattle, however, that marked a watershed event in which bloc tactics gained widespread media notoriety. For outside observers watching the events unfold on their television, it was a striking and symbolic scene of street warfare, where black-clad demonstrators put bricks through corporate windows and battled with police for three days, leading the local government to invoke emergency legislation and curfews, and asking the National Guard troops for assistance (Shantz, 2011: 54). Since the so-called "Battle of Seattle," black bloc tactics have become common at anti-globalization demonstrations in North America, among which have been the anti-G8/20 summits in Pittsburgh (2009) and Toronto (2010), and also the anti-Free Trade Area of the Americas summit (FTAA) in Quebec City (2001) and Miami (2003). Activists have also used bloc tactics to protest neo-liberal capitalism at other major events such as the anti-Olympic protests in Vancouver and the ongoing anti-austerity activities in Greece, where anarchists routinely take to the streets to protest, riot, fight with the police, and ostentatiously present their discontent with capitalism and the State (Avery-Natale, 2010:97; Van Deusen, 2010:10).

\section{Social War \& Insurrection}

Yet even the most militant street fighting does not involve armed conflict. Rather than assassinating public figures and officials, black bloc activists call for a social insurgency. The avoidance of assault against human bodies, for example, is a selfconscious rejection of tactics used by armed clandestine organizations that were 
historically Marxist-Leninist. The tactics are also a rejection of the anarchistic notion of the propaganda of the deed. As discussed in chapter one, some anarchists in the past advocated for direct acts of insurrectionary violence against the Bourgeois State by means of political assassinations and terrorism. However, today's anarchists believe clandestine organization for either capturing State-power or abolishing it immediately is inadequate, counter-hegemonic, and paternalistic and thus contradictory to the goal of liberating oneself from the matrix of domination. As Tiqqun, an anonymous collective that calls for black bloc tactics, explains:

"The RAF's attack on the "imperialist system"... and so many other guerilla groups has been easily suppressed. The failure was not one of this or that militant organization, of this or that "revolutionary subject," but the failure of a conception of war, of a conception of war that could not be reproduced beyond the sphere of organizations because it itself was already a reproduction [authors emphasis]...most documents from [RAF's] "armed struggle" are written in this ossified, used up, borrowed language that one way or another smells of Third International kitsch. The unique thing about Empire is that is has expanded its colonization over the whole of existence and over all that exists. It is not only that Capital has enlarged its human base, but it has also deepened the moorings of its jurisdiction...it is on this total terrain, the ethical terrain of forms-of-life, that the war against empire [should be] played out" (Tiqqun, 2011:67).

Tiqqun draws upon Foucault's notion of biopower to argue that groups like the

RAF and other militant guerrilla organizations were incapable of implementing a revolutionary program because they failed to grasp that relations of power and domination were not distributed from an archaic centre. This point is similar to one made by the Invisible Committee.

"The goal of any [social] insurrection is to become irreversible. It becomes irreversible when you've defeated both authority and the need for authority, property and the taste for appropriation, hegemony and the desire for hegemony. That is why the insurrectionary process carries within itself the form of its victory, or that of its defeat. Destruction has never been enough to make things irreversible" (2009: 130-131). 
Thus, bloc advocates believe that a military-style insurgency, be it communistic or anarchic, cannot succeed given that relations of power are dispersed throughout the social fabric. In fact, to capture State power would merely replace one system of totalizing domination (State-capitalism) with another (State communism), while implementing an anarchistic program to immediately dismantle the State would be inadequate. This is because the circulation of repressive power is believed to be part of a broader struggle within what bloc activists call social war and in order to challenge it, one must develop new, decentered forms of militant resistance.

Where civil war signifies a breakdown of the apparatus of the State, social war is understood by anarchists in the Foucauldian and Nietzschean sense as a type of lowintensity warfare enacted by the State against the social relationships of its own population in order to maintain its continued existence (see Foucault, 2003; Hodgson, 2007). Proponents of black bloc activities believe that the primary tactic of the State's social-war is subsumption. They contend that in late modernity, social war via subsumption is accomplished by constantly consuming citizens with work or by isolating them through instilling an artificial fear of an enemy "Other." It is believed that the citizen is not only stripped of social relationships in this social war, but they are also recomposed in terms of their language, habits, and inclinations. Thus, by subsuming all forms-of-life, the State destroys the possibilities of alternative social relationships and models of existence (Trocchi, 2011:305-307). As Tiqqun contends, "War can no longer be discounted as an isolable moment of our very existence; from now on, our every aspect of it is war" (Tiqqun, 2011: 67).

Rather than making demands on the State, which many anarchists claim only 
reaffirm its legitimacy, black bloc activists encourage the development of subversive tactics that are capable of disrupting State-capitalist order in an era where "pervasive State apparatuses dominate in multiple, intertwining, and invisible ways" (Thompson \& Williams, 2011: 273). As noted above and in the preceding chapters, Foucault's work has influenced contemporary anarchists. Like Foucault, today's activists contend that the relations of repressive power that lead to domination are no longer located within an archaic centre, and therefore, simply abolishing the State would be incapable of challenging it's pervasiveness in structure. However, Foucault was reluctant to engage in strategic discussions on how to resist domination and repressive power. To fill this gap, black bloc anarchists have taken inspiration from Giles Deleuze and Felix Guattari's analogy of the rhizome as one possible way of moving beyond Foucault's reluctance.

\section{Rhizomatic Resistance \& The War Machine}

In $A$ Thousand Plateaus, Deleuze and Guattari outline the possibilities of a nonhierarchical and decentralized resistance against the State-form. Like Foucault, they reject the traditional understanding of politics as instrumental, as it views social struggles as binary oppositions between a State and its rebels. However, for Deleuze and Guattari, the State is an abstract machine rather than a concrete institution, which essentially "rules" through multiple institutions and practices of domination. The State "overcodes and regulates" these minor dominations (reterritorialization), stamping all institutions with its imprint, and therefore, invoking itself throughout the matrix of domination. On this account, they call for a micro-politics of resistance where actors can deterritorialize from the State-form. Here they offer the spatial metaphor of the rhizome as a method of 
organizing it:

"[The rhizome] is composed not of units, but of dimensions, or rather directions in motion. It has neither beginning nor end, but always a middle (milieu) from which it grows and which it overspills. It constitutes linear multispecies with $n$ dimensions having neither subject nor object, which can be laid out on a plane of consistency, from which the One is always subtracted...the rhizome is an acentered, nonhierarchical, nonsignifying system without a General and without an organizing memory or central automation [my emphasis]..." (1987: 21).

Micro-political resistance should therefore be contextualized as a struggle between the State-form and what the authors call a nomadic, rhizomatic resistance (the "war machine"). ${ }^{15}$ Because the rhizome is non-linear, fluid, and without hierarchies, a method of resistance based on its structure allows one to embark on a line of flight-the creative, fluid, and liberatory escape from the stratification of the State-form and other forces of repressive power. Although the authors do not specify the exact details as to what tactics would be considered appropriate, they believe these lines of flight are available to us in a number of ways, as even the most intense 'strata' are riddled with them. To embark on it, one must first find a 'stratum or sphere of thought' within the existing system and familiarize themselves within it. In this process of familiarization, one should look for possible lines of flight by experimenting with the opportunities it offers, and the potentialities of deterritorialization. ${ }^{16}$

\footnotetext{
15 The term "War Machine" was inspired by Pierre Clastres A,cheology of Violence (2010). In his ethnographic studies of indigenous communities in South America, Clastres identifies the use of decentralized, non-hierarchical violence as something that is not inherently bad or good, but as a deliberate means to "territorial segmentation' and avoidance of any State formation. It is through this systemic and continuous violence, what Clastres calls the war machine that allows the communities to ward off the State and any formation of macro-domination.

${ }^{16}$ One analogy they offer is by contrasting between the board games 'Chess' and 'Go'. The authors believe the latter offers a symbol of rhizomatic resistance, as the opponent in the game does not have clear boundaries, thus requiring the player to strategize fluidly. As the authors write, "Chess is indeed a war, but an institutionalized, regulated, coded war, with a front, a rear, battles. But what is proper to Go is war without battle lines, with neither confrontation nor retreat, without battles even: pure strategy, whereas chess is a semiology" (Deleuze \&Guattari, 1987:353).
} 
"This is how it should be done: Lodge yourself on a stratum, experiment with the opportunities it offers, find an advantageous place on it, find potential movements of deterritorialization, possible lines of flight, experience them, produce flow conjunctions here and there, try out continuums of intensities segment by segment, have a small plot of new land at all times. It is through a meticulous relation with the strata that one succeeds in freeing lines of flight..." (1987: 161)

\section{Black Bloc Resistance as Rhizomatic}

As noted earlier, black bloc anarchists assume a similar understanding of deterritorialized power, that is, the belief that power relations, including repressive ones, are no longer concentrated in one particular point, but that "the world itself, its flows and its avenues, its people and its norms, its codes and its technologies" (the Invisible Committee, 2009: 108). Without a centre to attack, activists call for subversive tactics that are fluid and thus capable of interrupting the endless cycle of the constitution and reproduction of neoliberal subjectivities to rupture the matrix of domination (Thomson \& Williams, 2011:273).

"There is no reason that the interminable subsidies that numerous relatives are compelled to offload onto their proletarianized progeny can't become a form of patronage in favor of social subversion. "Becoming autonomous," could just as easily mean learning to fight in the street, to occupy empty houses, to cease working, to love each other madly, and to shoplift" (The Invisible Committee, 2009).

On this account, black bloc tactics are understood as one of many possible lines of flight, where subjects attempt to deterritorialize from State-Capitalist apparatuses. During a mass demonstration, for instance, black bloc subjects familiarize themselves within the protest space, then creatively target governmental and corporate property by smashing its windows or spray-painting slogans. In a situation where they are faced with police 
repression, they throw whatever physical objects they find at them, while some mislead them to allow other bloc subjects in continuing the destruction of private property. In the heat of the moment, participants also creatively build blockades against police lines using burning garbage disposals and/or newspaper stands found on the street (see Crimethinc, 2006).

\section{Subversion \& Psychogeography}

The black bloc call for subversion, however, also takes inspiration from Guy Debord and the Situationist International. According to Debord, the only way to overcome the repression of capitalist power was to take action for and by oneself, to "return to the pure pleasure of creativity, which, in effect, meant turning elements of the system —-spaces, imagines, objects — against themselves" (Graeber, 2009: 392; Debord, 1994). Debord was particularly interested in the transformation of urban space - or, what he called, the practice of psychogeography; of subverting the drab utilitarian logic of streets and thoroughfares to recreate the sense not only of community but also of the sacred (Graeber, 2009: 392; Debord, 1994). While Debord was interested in the act of subversion through artistic expression, black bloc activists take the idea of psychogeography a step further. The anonymous writers of Al Daggers Drawn, for example, contend that:

"The force of an insurrection is social, not military. Generalised rebellion is not measured by the armed clash but by the extent to which the economy is paralysed, the places of production and distribution taken over, the free giving that burns all calculation and the desertion of obligations and social roles. In a word, it is the upsetting of life. No guerrilla group, no matter how effective, can take the place of this grandiose movement of destruction and transformation" (2001:25). 
Thus, the primary purpose of black bloc subversion is to cause as much economic damage as possible and to be disruptive to the normal functioning of the businesses and government of a city. By draining financial resources, and, massively inconveniencing the State, activists believe it disrupts the existing State-capitalist order thereby allowing subjects to deterritorialize from it and temporarily regain agency (Avery-Natale, 2010). Consider another example. After the 1999 anti-WTO riots, the ACME collective published the following communiqué:

"When we [the black bloc] smash a window, we aim to destroy the thin veneer of legitimacy that surrounds private property rights. At the same time, we exorcize that set of violent and destructive social relationships which has been imbued in almost everything around us. By "destroying "private property, we convert its limited exchange value into an expanded use value. [...] A storefront window becomes a vent to let some fresh air into the oppressive atmosphere of a retail outlet (at least until the police decide to tear-gas a nearby road blockade). A newspaper box becomes a tool for creating such vents or a small blockade for the reclamation of public space or an object to improve one's vantage point by standing on it. A dumpster becomes an obstruction to a phalanx of rioting cops and a source of heat and light. A building facade becomes a message board to record brainstorm ideas for a better world" (cited in Van Deusen, 2010).

One can see that, through the act of sabotage, activists believe they can "emancipate" themselves-however temporarily - from the norms of constituted power. Here, smashing a window is believed to challenge both the particular policies and rules of the State (i.e. private property rights), but also the State itself. It is through this process that the "everyday" status of the world is itself called into question (Thompson, 2010: 143). This temporary transformation of the self that is experienced by black bloc activists through acts of violence is, of course, not a new phenomenon. One can recall Frantz Fanon's Wretched of the Earth, in which the connection between violence and politics is made explicit. Although one can highlight phenomenological similarities (Thompson, 
2010: 136), what perhaps separates black bloc violence from so-called 'revolutionary' violence is not only the desire to transcend counter-hegemony, but also prefigurative nonhierarchical organization.

\section{THE WAR MACHINE: PREFIGURING ALTERNATIVES THROUGH THE ORGANIZATION OF (INSURRECTIONARY) VIOLENCE}

\section{On Revolutionary Violence}

In the Wretched of the Earth, Fanon contends that decolonization is not simply the physical act of liberating a territory from an external colonizer. Decolonization is also a violent psychological act of freeing the consciousness of the native from the alienation caused by the colonization of territories. For Fanon, subjects emancipate themselves and transform society through violently acquiring what he calls a human soul. Through this process, the colonized subject undergoes a dramatic psychological transformation where they cease to be objects at the mercy of historical circumstances and become history's privileged actors. This process is not an abstract appeal to unhappy human potential, nor does it require a normative assumption of what it means to be human in order to operate. Rather, it begins from where the colonized subject initially refuses to be colonized (Thompson, 2010: 136-7; Fanon, 1963).

Once refusal has taken place on a conscious level, and once the anti-colonial struggle moves through the realm of immediate physical violence and into the field of mediated politics, Fanon claims that a profound shift begins to occur. However, what emerges from this process did not exist prior to colonization. Anti-colonial violence is not redemptive; it does not signal a return to origins or to some prior moment. Instead, the 
anti-colonial struggle expresses a redemptive impulse seeking to realize alternative possibilities in the present because it orients to the unfulfilled promise of the past (Thompson, 2010: 136-7; Fanon, 1963).

One can see a striking similarity between Fanon's anti-colonial violence and black bloc subversion. The Invisible Committee writes:

"We live under an occupation [referring to the State-form]. Undocumented immigrants are rounded up in the middle of the street, unmarked police cars patrol the boulevards, metropolitan districts are pacified with techniques forged in the colonies... we are reminded of it everyday. These are reasons enough to no longer let ourselves be beaten down, reasons enough to organize our self-defense.[...] The police are not invisible in the streets, they simply have the means to organize, train, and continually test new weapons. Our weapons, on the other hand, are always rudimentary, cobbled-together, and often improvised on the spot" (2009: 114-116)."

As briefly discussed in chapter one, rather than being neutral peacekeepers, anarchists believe that apparatuses such as the police are violent agents of State repression, who inevitably (re)-affirm and defend both State-power and private property rights. On this account, activists believe that street fighting with the police is a commitment to unified action to defend themselves and other demonstrators against the violence of State "colonization." In addition to defensive tactics, activists also advance acts of violence against the police, such as throwing stones, bottles, and Molotov cocktails to "decolonize" (or deterritorialize) an urban space from the State-form, whether it be temporarily liberating a protest space, or permanently defending against a squat eviction (Gordon, 2008: 100).

Consider, for instance, the events surrounding the Québec City protests against the FTAA summit in 2001 . Security officials built a massive fence around the entire section of the downtown core where the FTTA delegates were to hold their conferences and 
meetings. For activists, the fence presented a striking symbol of the "exclusionary governance practices accompanying neoliberalism" (Shantz, 2011:61). In addition to a security perimeter, there was massive police presence throughout the streets, where protesters and observing crowds were attacked with tear gas, rubber bullets, and water canons. In this climate, the formation of black blocs demonstrated a power symbol of resistance in the face of massive and sustained repression by attempting to liberate "public space." Black Bloc activists not only engaged in street fighting with the police, but activists also attempted to literally tear down the fence:

"The three-kilometer 'wall' constructed through the centre of Quebec City, to shield the heads of state junketing inside from any contact with the populace, became the perfect symbol for what neoliberalism actually means in human terms. The spectacle of the Black Bloc, armed with wire cutters and grappling hooks, joined by everyone from Steelworkers to Mohawk warriors to tear down the wall, became - for that very reason- one of the most power moments in the [anti-globalization] movement's history" (Graeber, 2002: 65).

The bloc attack against the fence therefore represents an attempt to dramatically and symbolically shatter State-power, and also private property rights and neoliberal globalization; all of which anarchists hold to be illegitimate. It demonstrates a negation against the material manifestation of "the most vigorously defended beliefs of capitalism and liberal democracy" (Shantz, 2011: 53). Yet, the objective of black bloc activities such as those in Québec City were not make demands on the State, or to return to a prior origin or moment, such as a return to a nomadic and anarchic past. Like Fanon, activists believed that through violently liberating space, one also learns to psychologically act.

"Attack is the refusal of mediation, pacification, sacrifice, accommodation, and compromise in struggle. It is through action and learning to act, not propaganda, that we will open the path to insurrection, although analysis and discussion have a role in clarifying how to act. Waiting only teaches waiting; in acting one learns to act" (The Invisible Committee, 2009). 
Once the subject refuses to be passive, then commits acts of sabotage at the mediated political field, black bloc anarchists believe it not only disrupts the existing hegemonic order to emancipate subjects temporarily, but it also deterritorializes and therefore opens space for expressing radical alternatives in the present.

\section{Prefigurative Violence as Expressing Radical Possibilities}

In his studies of colonization in North Africa and the Middle East, Fanon claims that by immersing themselves in the rituals of an anachronistic spirituality, some of the elders among the colonized are seeking to return to a mythological and contradictory past that existed just prior to decolonization. However, for younger radicals, this solution seemed inadequate and dangerous. This does not mean that the younger anti-colonial fighter refrained from talking about this mythological past, but rather they drew upon discourses of freedom as a means of provoking anti-colonial action. Fanon writes:

"The great figures of the colonized people... are always those who led the national resistance to invasion. Behanzin, Soundiata, Samory, Abdel Kader all spring to life again with peculiar intensity in the period which comes directly before action. This is proof that the people are getting ready to move forward again, to put an end to the static period begun by colonization, and to make history (1963: 69)."

However, as A.K Thompson notes, while accounts of such violence are seductive, the decisive moment marked by violence is simply the gate through which the subject must pass in order to regain the capacity to act politically. Indeed, this is a necessary first step, however it does not contain its own content thus posing the inevitable question:

"what will be produced in the space opened up by violence?" (Thompson, 2010: 140). It is precisely in this moment that black bloc violence is separated from Fanon's 
revolutionary violence. In contrast to the latter, anarchists not only reject the notion that one must capture political structures to sustain a revolutionary project, but black block organization prefigures and also embodies the alternatives anarchists envision.

As discussed in the preceding chapters, prefigurative politics remain an important component of anarchic organization, and the formation of black blocs is not an exception. This is further elaborated by the Invisible Committee, who contends that an act of sabotage is not about (re)-possessing the territory of the State-form, as Fanon would have advocated, but about increasing the density of alternative spaces and ways of living, of "circulation, and of solidarities to the point that territory becomes unreadable, opaque, to all authority." The collective does not want to occupy the territory; they want to be the territory (the Invisible Committee, 2009: 108). In other words, not only do activists attempt to "liberate" themselves by deterritorializing from the State-form, but the very methods of bloc organization —consensus decision-making, aesthetical uniformity, - affinity group structures, and non-hierarchical leadership -itself demonstrates the visions of new mode of existence where actors learn to organize themselves outside powers that repress them.

In addition to embodying the alternatives, black bloc anarchists do not believe their tactics will achieve a utopian finality, or a permanent emancipation. For activists, there are no 'final struggles,' but a series of struggles on a multitude of fronts. As noted earlier, activists believe they are simply one of many possible forms of rhizomatic resistance that will involve continuously warding off systems of domination to open space for radical experimentation. Black Bloc resistance thus expresses the desire of a revolution of becoming; that is, yet-to-come, which is permanent and ongoing. As 
Torrance Hodgson elaborates:

"The revolution is now, and we must let the desires we have about the future manifest themselves in the here and now as best as we can. When we start doing that, we stop fighting for some abstract condition for the future and instead start fighting to see those desires realized in the present ... Whether the project is a squat, a sharing of free food, an act of sabotage [my emphasis added], a pirate radio station, a periodical, a demonstration, or an attack against one of the institutions of domination [my emphasis added], it will not be entered into as a political obligation, but as a part of the life one is striving to create, as a flowering of one's self-determined existence" (cited in Gordon, 2008: 41).

On this account, one can see that black bloc violence is rhizomatic, subversive, and prefigurative; blocs stand as a practical micro-political response to a given situation, and also act as a symbol of the larger vision of societal changes. But rather than simply destroying State-capitalist power for the purpose of sustaining a hegemonic program, activists believe the process of sabotage allows actors to open space for experiment. Unlike hegemonic revolutionary programs, the idea is not to capture power, reform it, or necessarily abolish existing political structures but instead, to establish oneself out of the existing order, to resist it, and to open space within which new social relationships and political identities can be formulated. Thus, black bloc sabotage illustrates an attempt by activists to engage in a politics of resistance that attempts to transcend repressive boundaries where anarchic revolution is yet-to-come.

One can also see the expression and embodiment of new social relationships and identities through the uniformity of an all-black aesthetic. As I will elaborate below, black bloc resistance cannot be separated from its aesthetics, as the latter plays a crucial role for prefiguring alternatives. While its main purpose is to avoid police surveillance and identification, black bloc uniformity - and in particular wearing masks - also allows for the prefigurative experimentation of new anarchic identities as yel-lo-come. Black 
aesthetics allow activists to temporarily erase their previous identities, and in doing so, it allows activists to express and embody a new existence. However, given that subjectification is also perceived as always potentially dangerous, this new existence is paradoxically embodied.

\section{THEATRE MACHINES: ON THE AESTHETICS OF PREFIGURING RADICAL IDENTITIES YET-TO-COME}

\section{(Un)masking the Machines}

According to Deleuze and Guattari, the face represents the signification of the subject. As the authors write, "the form of the signifier has a substance, or the signifier has a body, namely the face (the principle of the facility traits, which constitutes are territorialization)" (1987: 117). The face is the signification of the self in relation to others, and it is upon the face that one may reterritorialize after having deterritorialized into a "rhizomatic line of flight." In other words, once an actor has temporarily rejected subjectivity, therefore entering into a line of flight, the actor will "always reterritorialize in some way, meaning that one will regain subjectivity, and this reterritorialization is always onto a face" (Avery-Natale, 2011: 101). The face, however, is not limited to the frontal presentation of the head. It can also expand to other aspects of the self, turning those aspects into a facility. As Deleuze and Guattari clarify, "the face is a surface [...] if the head and its elements are facialized, the entire body can also be facialized" (1987:170). This expansion of the face can occur, for example, through fetishization, when one allows other parts of the body to represent the self. Therefore, the face is the signification of one's subjectivity and, as such, other aspects of this representation can 
obtain 'faceness.' Nonetheless, in our culture, the face often facializes on the front-wardfacing head. Thus, it is here where we often experience the other's subjectivity first, although this does not necessarily occur at all times (Deleuze \& Guattari, 1987: 170; see also Avery-Natale, 2011: 101).

Given that the face is where we experience the other's subjectivity, to cover it with a mask allows the 'other' to temporarily express a new subjectivity. As Deleuze and Guattari argue, the mask assures the erection, the construction, of the face, or "the facialization of the head and the body." The mask has now become the face itself, as the abstraction or operation of the face. Never does the face assume "a prior signifier or subject [because] the face is a politics" (Deleuze \& Guattari, 1987: 181). In other words, the face signifies the subjectification, and the mask comes to represent this subjectivity; "the mask erases the old subject and represents the new" (Avery-Natale, 2011: 102). Black bloc activists similarly perceive masks as crucial for resisting against the Stateform. Not only does it allow the activist to subvert State-capitalist subjectification, but an all-black aesthetic also represents possibilities of radical alternatives by allowing an activist to temporarily embody an identity of choice not constituted by the State-form. As one black bloc activist expresses:

"We will remain faceless because we refuse the spectacle of celebrity, because we are everyone, because the carnival beckons, because the world is upside down, because we are everywhere. By wearing masks, we show that who we are is not as important as what we want, and what we want is everything for everyone" (cited in Graeber, 2009: 407).

Yet, going beyond the mask, activists also deliberately wear all black clothing. In contrast to other colours, anarchists believe that "blackness" as a style of clothing makes explicit "an obliteration of meaning, a kind of physical absorption of all light rays that 
transforms the body dressed in black into a transparent, or invisible entity" (Calefato cited in Avery-Natale, 2011: 105). ${ }^{17}$ As Deleuze and Guattari note, while a mask erases the prior facialization, the facialization spreads across the entire body which itself becomes a face. Thus, the erasure of the previously existing identity spreads across the entire body, and therefore, the all black aesthetic from head-to-toe also become the face (Avery-Natale, 2011: 105).

It is precisely the moment of 'blending in' that is attractive for black bloc activists. Through acts of sabotage and violence, the black aesthetics attempts to create a fleeting moment where autonomy from the State-form is literally embodied and experienced; it is a space of temporarily liberated territory in which "the laws and arbitrary power of the State no longer apply," allowing the activist to explore new, non- hierarchical identities of choice (Graeber, 2009: 407). As one activist writes:

"Masks are also a mask of identity. By putting on a black mask, you are not hiding your identity - you become part of a common identity. If we all wear masks, then our differences that others seek to divide us by-our skin color, our gender, our age-are all cloaked behind a common individual identity which unifies us in purpose and in spirit. By becoming a Black Bloc, we attempt to shed the divisions between us under one collective face and voice" (cited in Van Deusen, 2010: 272).

Because anarchic organization refuses hierarchies and formalized leadership, masks and black aesthetics are crucial to ensure movement "leaders" or "figureheads" are not elevated, as they might receive special attention either favorably by journalists looking for interviews, or negatively by the police who attempt to arrest and target perceived "ringleaders" (Shantz, 2011: 51). Thus, by wearing a mask and an all-black attire when

\footnotetext{
${ }^{17}$ The colour black has also historically been associated with anarchist symbolism. The black flag, for instance, is a symbol for anarchists as a way of expressing negation of all state-forms, and also a symbol of resistance, which contrasts the white flag of surrender. See lain McKay' an Anarchist FAQ (2008).
} 
engaging in violent acts, the black block activist refuses to open dialogue or negotiation with the State. On the contrary, the activist attempts to subvert its repressive power, including its subjectification.

\section{The Paradox and Limitations Behind Black Blocs}

Indeed, black bloc subjectification is always intended to be partial and never complete. As Avery-Natale explains, while the deterritorialization of the masking practice is a line of flight away from subject and towards a becoming of whatever, deterritorialization always necessitates a reterritorialization and thus one will always become re-subjectified. The erasure of subjectification performed by black bloc aesthetics then will always inevitably return to identity. The black bloc will never prevent this reterritorialization onto the identification of the "black bloc anarchist" because this subjectivity is necessary for the progression of the black bloc; the subjectivity of 'anticapitalist' or 'anti-authoritarian', for example, is necessary for the process of insurrection and social transformation and thus the erasure must always be partial until after the insurrection (Avery-Natale, 2011: 105).

However, the inevitable return to identity in the struggle against the repressive powers of the State-form suggests that there is always a danger of essentializing identity itself, regardless of whether it was constituted by the State or by one-self. In "For the

Insurrection to Succeed, We Must First Destroy Ourselves", Alex Trocchi writes:

"...the proliferation of identity-based politics and subculture is merely another form of spectacular society. So it should be of no surprise that even as faith in neo-liberal capitalism collapses, a polis based on identity remains as strong as ever, as even self-professed [postmodern] revolutionaries are trapped within a politics based on images...[...]... Since subsumption has nearly stripped each person of any ability to hold onto her own presence, 
identities come and go, no more afflicting than a passing crush or the value of shock. These [anti-authoritarian \& anti-capitalist] identities at their core are then just new brands of citizenship in the social war..." (Trocchi, 2011: 312).

Trocchi raises an interesting paradox: the identity of the black bloc anarchist, with its all-black dress code, its destruction of corporate property, and with its anti-state and anti-capitalist subjectivities, itself risks becoming permanent. The problem for Trocchi, however, is not that black bloc activists are incorrectly fighting the social war, but that the black bloc anarchist has become identified with a particular kind of image, and predictable set of practices. This predictability, in turn, has allowed the State to develop methods of neutralizing them. By implementing a number of legal measures and surveillance mechanisms, it has become difficult for black blocs to organize successfully, thus limiting its radical possibilities.

One of the reasons black blocs were effective in Québec City was because it surprised the State. In an era where the police were unfamiliar with the decentralized, rhizomatic organization of black blocs, the anonymity behind blocs offered protection for a number of activists (Shantz, 2011: 63). The repressive power of the State, however, has, exponentially increased over the last decade. Securitization has become the dominant paradigm of the State, where the technologies of control, surveillance, and preemptive arrest have become permanent and militarized (see Newman, 2010; Shantz, 2011; Fernandez, 2008; Franks, 2007). In keeping with this trend, State forces in the Global North have come to perceive the formation of Black Blocs as "internal" security threats. Police departments throughout Western liberal democracies have refined their strategies to ensure that bloc tactics are neutralized far in advance. With the help of spy agencies (FBI, RCMP), they now prepare for months in advance of a march, action, or mass demo 
that occurs on public streets, going as far as to preemptively targeting and arresting participants before any demonstration even occurs. This has not only had the effect of limiting militant dissent, but it has also made it difficult for activists of color, immigrants, undocumented migrants, and the poor to utilize black bloc tactics, especially considering that they already face increased police surveillance within their own communities on a daily basis (Shantz, 2011: 63; see also Fernandez, 2008).

Although anarchists do not desire hegemonic politics, some have argued that social insurrection can only be sustained by overcoming the identity of the black bloc anarchist itself; instead, a new collective rhizomatic force against the social war must be constructed, where tactics are unpredictable, and where anyone can participate in and form new social relationships in some meaningful way:

"While it may be impossible to destroy identity entirely, insurrectionists [black bloc anarchists] can abolish their identity 'as insurrectionaires' by acting in such a way that tends to dissolve the boundaries inherent in a social terrain divided up into identities rather than just falling back into the even more isolated subjectivity of 'the anarchist who has a critique of identity"' (Trocchi, 2011: 322).

Thus, the danger of essentializing black bloc identities is that it allows the Stateform to further divide communities to conquer dissent. As Trocchi notes, from the standpoint of the State and capital, identity is to be encouraged insofar as to label one as "different" and, therefore, capable of being discovered and isolated by the State's social war. As Trocchi clarifies, as long as any group - be it the black bloc anarchist, the Muslims, the Jews etc — can be isolated in terms of identity, they can also be destroyed by the State. The crux of the problem is not being anti-authoritarian or anti-capitalist or an anarchist, but identity itself (Trocchi, 2011: 312-313). 


\section{Concluding Remarks}

My objective throughout this chapter was to explore how one can envision a militant, decentralized, anarchic resistance that can transcend hegemonic and essentialist methodologies. Here I have demonstrated that the formation of black blocs, and their call for social insurgency, has opened the doors to the possibilities of transcending it. We have seen, for instance, that black bloc organization produces a dual effect. Externally, black bloc tactics are believed to subvert the major institutions of the State and symbols of neoliberal capitalism thus temporarily allowing an activist to regain agency and emancipating her-self from State-capitalist power. Internally, its organization structure and aesthetics prefigure radical platforms where alternative subjectivities are expressed through ritualized forms of resistance. Black bloc violence thus has both practicalinstrumental and complex symbolic-expressive dimensions. The practical element involves an attempt by activists to directly transform their social environment via nonmilitary and non-hegemonic subversion, while the symbolic element emphasizes a dramatized representation via all-black aesthetics to produce new political antiauthoritarian and anti-capitalist identities (Juris, 2008: 124).

However, while indeed they signal an era of a new, post-utopian method of politics, the paradoxical and essentialist limitations have yet to be transcended. To clarify. I am not suggesting that anarchists should abandon militant rhizomatic tactics. On the contrary, as explained throughout this chapter, I believe black bloc tactics open the doors to the possibilities of new, post-utopian modes of organization and resistance. However, they have yet to transcend the limitations discussed above. Perhaps for any post-utopian social transformation to remain successful, anarchists must not only (re)-strategize 
militant subversive tactics, but also abolish the black bloc identity in the process. 


\section{CONCLUSION \\ AN ENDLESS TRANSMISSION}

"One of the advantages of being disorderly is that one is constantly making exciting discoveries."

- A.A Milne

The aim of this thesis was to explore the relationship between contemporary anarchic theory and social transformation. I began this exploration by asking series of questions: What is anarchism? What is domination? What are the possibilities of emancipation and resistance? How do anarchists envision social organization? And what are the possibilities of living in anarchy? Although anarchism is a project that seeks to dismantle all forms of social, economic, and political hierarchies and domination, we have seen that the milieu initially began as a 'movement of movements' that conveyed a misguided understanding of power, human nature, and domination.

As I demonstrated in chapter one, at the core of "classical" anarchist theory were essentialized assumptions about human nature and essence. Classical thinkers, such Bakunin and Kropotkin, believed that "the people" existed outside the realm of "artificial" power. They argued that subjects inherently possessed certain "natural" traits that would allow them to live peacefully with one another if only they were free from the corrupting power of the State. For classical anarchists, relationships of power and systems of domination-be it white supremacy, patriarchy, or capitalism, among others-were believed to gravitate from the centralized State. Anarchists perceived the State as the greatest source of domination, which violently protected itself through apparatuses such as the police, the army, and the judiciary.

For the reasons noted above, anarchists believed that the Marxist project of capturing State power, and initiating a communist program, was a terminally flawed 
endeavor, as that would only replace one form of domination (Liberal-capitalism) with another (State-communism). Although anarchists concurred with Marx in that the workers needed to reclaim the means of production while simultaneously destroying capitalist social relations, the crux of the anarchist project was to organize a leaderless social revolution that would abolish the State and all of its apparatuses. This, anarchists argued, would allow subjects to replace them with a horizontally aligned network of voluntary associations, based on the principles of direct democracy, solidarity, and mutual aid. Once the masses abolished the State, and social transformation was complete, they would be emancipated from the matrix of domination. While anarchic thinkers debated the merits of what organizational model would be best suited for a postrevolutionary society, most anticipated a coming revolution where the State would be abolished, regardless of the strategies and visions proposed.

Upon further investigation, however, I discovered that there has been a shift in anarchic theory. Contemporary anarchic thinkers have begun abandoning anarchism's essentialist and humanist ontological foundation. They have invoked a poststructuralist inspired critique to unmask the dangers and limitations of classical theory and praxis. Foucault's work, for instance, has played a significant role in compelling today's anarchists to conceive of power as decentered and exercised from innumerable points throughout the fabric of society. Anarchists no longer believe one can simply abolish the State and expect human beings to naturally form egalitarian social relationships and institutions. They contend that traditional anarchism, like the Marxist project, does not completely fall outside the realm of hegemonic politics, and, in fact, falls into the same authoritarian trap. 
In addition to recognizing that power and domination can no longer be located to an archaic centre, another crucial shift between classical and contemporary anarchic theory is that the latter do not perceive power as inherently bad or repressive, but rather, productive. Today's anarchists, for instance, contend that both Bakunin and Kropotkin misunderstood the concept of power, as their post-revolutionary visions, be it anarchocollectivism or anarcho-communism, are themselves proposals for new set of power relations, albeit a decentralized, non-hierarchical form. This has led anarchists to widen their perspective on how domination forms. Relations of power, today's anarchists argue, become relations of domination only when the flows of power become blocked and congealed; when they form repressive, and unequal hierarchies that no longer allow reciprocal relationships (see Foucault, 1988: 3). Thus, anarchists believe that institutions such as the State are merely an effect of repressive power relations that have become crystallized into relations of domination.

Yet for anarchists, macro manifestations of domination, be it the State or capitalism, are not the only concern; other, subtler forms of domination must also be equally resisted. Because our everyday actions involve power, today's anarchists believe that all power relations have the potential to form into relations that dominate us. This is particularly true in an era of biopower-the technology of power that regulates the biological livelihood of people to manage them as particular subjects and identities. As I demonstrated in the second half of chapter one, the productive aspect of biopower poses a danger for the anarchist project. More specifically, it poses a risk where the anarchist identity itself can lead to relations of domination. Thus, for many activists, one must not 
only reject a programmatic revolution, but the revolutionary subject-be it the people, the workers, the proletariat, or the anarchist-must also be questioned.

The (re)-conceptualization of power, subjectivity, and domination, however, has not convinced anarchists to entirely abandon the anarchist project. Nor has it compelled them to abolish the anarchist identity. Because Foucault did not offer suggestions as to how one could organize to transcend the limitations of essentialism, many anarchists have invoked Derrida's deconstructive practice to escape its trap; thus, opening the possibilities of anarchic resistance and social transformation. This signals the emergence of a new, post-utopian anarchism, which does not abandon strategic essentialism, but calls for a politics of becoming, and revolution as yet-to-come; a politics where activists do not anticipate a utopian finality; a politics where radical activism is a process of warding off the matrix of domination, while discovering new spaces for experimentation of a radical 'outside' on the 'inside'. This is most clearly embodied through anarchic prefigurative practices.

As I illustrated throughout chapter two, anarchists prefigure alternatives within their own organization practices against systems of domination. The organizational structure behind anarchist networks, groups, and collectives themselves embody and outline possible visions for a future anarchic society. Although there are certain paradoxical and contradictory norms, models such as spokescouncils, affinity groups, and consensus-decision making are not simply organizational tools for mass protest, but also offer post-utopian alternatives to both the State-form and judicial system. By exploring these models, and considering their merits and limitations, it reveals how anarchists envision social organization, and what their possibilities are. 
I argued, for instance, that spokescouncil assemblies are not only an assemblage of diverse activist groups that come together to organize mass demonstrations, but the model itself is a macro-organization vision for a multitude of communities to come together and coordinate decisions that would extend beyond their terrain. What is unique about activists organizing around spokescouncil assemblies is that they are attempting to transcend hegemonic politics. By developing a politics that parallels Derrida's notion of singularities and différance, spokescouncils act as a network that is both fluid and informal. Activists only converge around them when necessary, depending on the time, place, and context, without governing authorities, fixed boundaries, and formal memberships.

As we have seen with the example of the Toronto Mobilization Community Network (TCMN), groups that take part in spokes are neither required to change their own organizational structures, nor partake in actions they consider inappropriate. Moreover, the aim behind a spokescouncil is not for developing schematics on how one can strategize to abolish the State-form. It is, instead, conceived as a space that allows activists to freely share ideas and resources among each other to coordinate direct actions against various pockets of domination in a decentered way. This, in turn, allows for subjects to not only collectively subvert elements within the existing matrix of domination, but to also experiment and discover new alternatives and identities as yet-tocome.

While spokescouncils highlight the movement(s) macro-structure, anarchic organizing mostly takes place on the micro-level, particularly around the affinity group model. This model is not only an organizational tool for building resistance against 
institutions of domination, but many groups also use it in order immediately offer 'practical' alternatives to the State-form. The most significant element of affinity groups, however, is their use of consensus-decision, which offers a possible vision for organizing a future anarchic community or neighborhood without law's violence. Rather than being coerced by the majority or a ruling minority, consensus mechanisms such as reservations stand asides, and blocks highlights a decision-process that can increase the likelihood that a collective decision will be voluntarily carried out by those who make it.

There are, however, limitations behind both spokescouncils and consensus decision-making. The paradox behind both is that neither can completely escape the trap of essentialist norms. Although assemblies open space for communication and coordination among diverse groups, spokescouncils continue to exclude participants and organizations that do not necessarily fit into the assembly's ethical norms, even if one can find commonalities with the excluded groups. Most assemblies, for instance, formulate guiding principles and or hallmarks that participants consent to. The difficulty is that doing so ignores certain practical realities of 'the real world.' In our era of technological globalization, different communities would most certainly need coordination and communication among each other, even between those that may vehemently disagree with each other.

Similarly, consensus decision-making opens the doors to the possibilities of a decision-making process that attempts to transcend law's violence. However, the process in its current form is incapable of doing so, as it continues to be limited by its structural contradictions. Larger affinity groups, for instance, may use techniques such as supermajorities or consensus minus two during 'emergency' situations or during so- 
called "crucial" decisions. The problem with this approach, however, is that it violates the fundamental principle behind consensus - the rejection of majoritarian intervention. Moreover, while today's anarchists do not convey a benign understanding of human nature, consensus decision-making is still limited by humanist assumptions. Even though proponents of consensus argue that conflicts need not be resolved, the process still assumes that a "rational" subject will be capable of overcoming them, whether by solving them or not.

Despite their imperfections, both spokescouncils and consensus decision-making open the doors to envisioning a possible future anarchic social form. While they may not applicable to all aspects of social life, one cannot deny their potentialities, as they are continually used and experimented with by activists. Anarchists, however, do not believe these models are enough in subverting macro-domination. The inevitable reality is that institutions such as capitalism, the State, and its various apparatuses, are forces that are self-protecting and, therefore, evolve to ensure the continuation of their existence. Many anarchists, therefore, believe that these structures must also be actively fought against through acts of militant resistance. What I have argued, however, is that the militant, and sometimes violent tactics some advocate not only highlight a new insurrectionary form of resistance that rejects the physical harm of human bodies, but their organization also prefiguratively desires a decentered, post-utopian social transformation.

The most notable form of prefigurative militant resistance within the contemporary anarchist milieu is the formation of black blocs. As I argued in Chapter Three, black bloc tactics - such as hurling stones and Molotov cocktails, street fighting with police officers, sabotaging corporate property - and the aesthetics of the uniform 
worn by those who perform it, not only expresses the desire for a social transformation process without a hegemonic program, but they also prefiguratively allow subjects to explore new forms of revolutionary identities as yet-to-come, albeit in a paradoxical manner.

Instead of assassinating public officials, black bloc activists call for a social insurgency inspired by thinkers such as Foucault, Deleuze, and Debord. This insurgency calls for the subversion of daily life through decentralized, rhizomatic means that includes actions such as property destruction and confrontations with the police. The idea is not to make demands on the State, but to cause as much economic damage as possible and disrupt the normal functioning of neoliberal social life. Activists believe this subversion allows for subjects to temporarily regain agency. However, not only do black bloc anarchists attempt to temporarily liberate themselves from the State-form, but the methods of their organization - consensus decision-making, aesthetical uniformity, affinity group structures, and non-hierarchical leadership - are themselves representative of the future possibilities of a new mode of existence. Here, actors attempt to militantly overcome the powers that repress them while simultaneously experimenting with new alternatives and identities as yet-to-come.

Black Bloc activists, for instance, cover their faces and wear all-black clothing, which is an important component to their tactics. This indicates that bloc activists wish to resist against domination outside of the realm of identity politics. While the primary purpose is to avoid police surveillance, the all black aesthetics allow activists to erase their previous identity, therefore allowing the subject to temporarily embody their identity of choice. By wearing masks and all-black attire, it demonstrates that 
black bloc activists do not desire an essential political identification, be it anarchist, communist, or autonomist. Instead, it signals the desire for politics where activists reject State subjectification.

However, while the intentions behind black bloc subjectification are partial and never complete, the paradox is that it risks falling into an essentialist trap, as the "black bloc" activist, with their black shoes, black sweaters, and black masks, can become a permanent 'anarchistic' identity. The danger behind this subjectification is not simply (re)-producing essentialist norms, but that it may also allow the State to divide communities and conquer dissent. In an era of globalization, the techniques of repressive powers used by the modern State have become far more complex, making it difficult for black blocs to organize successfully, and therefore limiting its radical possibilities.

At the cusp the twenty-first century, direct actions at mass demonstrations were often met by large violent police presence. Under these circumstances, where being out on the street led to mass arrest and detention, black bloc anonymity provided protection. Over the last decade, however, the police have shifted their tactics to "zero in" on black blocs, sometimes targeting participants even before a demonstration starts. After the New York City attacks on $9 / 11$, securitization has become the dominant paradigm of the modern State, where the deployment of strategies and technologies of control, surveillance, and pre-emptive arrest has exponentially increased. This, in turn, has not only posed a risk in the effectiveness of black bloc tactics, but it has also made it largely undesirable to many activists that might be an immigrant, a person of color, an undocumented migrant, or a poor person, given that they already face increased police surveillance of their own communities. 
The increased securitization of the State, however, has posed a risk not only for black bloc tactics, but also, threatened the desire to escape the State-form itself. Over the last few years, we have witnessed a dramatic change in the operations of repressive power. Under the pretext of fighting 'terrorism', many radical movement actors, including anarchists, environmentalists, and anti-capitalists, have been subjected to an increased State Surveillance that is accompanied by stronger legislative control. As Benjamin Franks notes, the "heroic nomenclature of postmodernism, of flexibility, openness, pluralism and risk-taking" has moved towards a more conservative disposition, where the dominant political discourses has stressed "safety, security, and fixed identity and shared universal values" (Franks, 2007: 143). In light of this authoritarian turn, the structural paradoxes, and the inability to transcend the violence of law within current anarchic practices signal that an escape from the matrix domination is not currently plausible. This is not to suggest that one should abandon the commitment to a politics of post-utopian resistance and methods of organization. It also should not suggest that one should abandon envisioning radical alternatives as yet-to-come.

While anarchic practices in its current form may not be fully adequate overcoming domination and repressive power, they at the very least allude to the fact that human possibilities are not fixed, and that collective direct action, no matter how small, can contribute to pockets of "emancipation", whether its ensuring that an undocumented migrant is not deported, or whether its ensuring that a repressive legal measure, such as a surveillance bill, is not passed through parliament. Derrida once wrote the political desire for radical democracy is forever destined to its own non-satisfaction. Radical politics is a preference for what can never be realized in a final form or ideal adequacy (see Derrida, 
1994). It is in this sense that a politics of post-utopian anarchism will forever be a prefigurative politics, as it can never have an orientation or directedness towards an ideal utopian end. However, a picture may become clearer with thought and practice; by attempting to ward off the State through prefigurative experimentation and direct-action, and by deconstructing, unmasking, and exposing limitations of its organization. 


\section{Bibliography}

Anon. At Daggers Drawn. London: Elephant Editions, 2001.

Avery-Natale, Edward. "We're Here, We're Queer, We're Anarchists: The Nature of Identification and Subjectivity Among Black Blocs." Anarchist Developments in Cultural Studies. Post-Anarchism Today 1 (2010): 95-115.

Bakunin, Mikhail. Bakunin on Anarchy: Selected Works by the Activist-Founder of World Anarchism. Ed. Sam Dolgoff. New York: Random House, 1971.

Bakunin, Mikhail. God and the State. New York: Dover Publications, 1970.

Bakunin, Mikhail. "The International Revolutionary Society or Brotherhood (1865)." No Gods, No Masters: An Anthology of Anarchism. Ed. Daniel Guérin. Oakland, CA: AK Press, 1998. 153-65.

Bakunin, Mikhail. Marxism, Freedom and the State. London: Freedom Press, 1950.

Bakunin, Mikhail. Political Philosophy: Scientific Anarchism. Ed. G.P Maximoff. London: Freedom Press, 1984.

Benjamin, Walter. "Critique of Violence." Reflections: Essays, Aphorisms, Autobiographical Writings. Ed. Edmund Jephcott. New York: Schocken, 1986. $277-300$.

Bey, Hakim. T.A.Z.: The Temporary Autonomous Zone. Williamsburg, NY: Autonomedia, 1991.

Billington, James H. Fire in the Minds of Men: Origins of the Revolutionary Faith. New York: Basic Press, 1980.

Call, Lewis. Postmodern Anarchism. Lanham, MD: Lexington Books, 2002.

Chomsky, Noam, and Michel Foucault. The Chomsky-Foucault Debate: On Human 
Nature. New York: New Press, 2006.

Clark, Samuel. Living Without Domination: The Possibility of an Anarchist Utopia. Aldershot, England: Ashgate, 2007.

Clastres, Pierre. Archeology of Violence. Ed. Jeanine Herman. Los Angeles, CA: Semiotext(e), 2010.

Cohn, Jesse S. Anarchism and the Crisis of Representation: Hermeneutics, Aesthetics, Politics. Selinsgrove: Susquehanna University Press, 2006.

Conway, Janet. "Civil Resistance and the Diversity of Tactics in the Anti-Globalization Movements: Problems of Violence, Silence and Solidarity in Activist Politics." Osgoode Hall Law Journal 41.2 (2003). 505-529.

Crimethinc. Recipes for Disaster: An Anarchist Cookbook. Salem, OR: Crimethinc ExWorkers Collective, 2006.

Critchley, Simon. Infinitely Demanding: Ethics of Commitment, Politics of Resistance. London: Verso, 2007.

Curran, Giorel. 21st Century Dissent: Anarchism, Anti-globalization and Environmentalism. Basingstoke: Palgrave Macmillan, 2006.

Day, Richard J. F. Gramsci Is Dead: Anarchist Currents in the Newest Social Movements. London: Pluto, 2005.

Debord, Guy. The Society of the Spectacle. New York: Zone, 1994.

Deleuze, Gilles, and Félix Guattari. A Thousand Plateaus: Capitalism and Schizophrenia. Minneapolis: University of Minnesota, 1987.

Derrida, Jacques. "Force of Law: The 'Mystical Foundation of Authority"' Ed. Drucilla Drucilla, Michel Rosenfeld, and David David Carlson. Deconstruction and the 
Possibilities of Justice. London: Routledge, 1992. 3-67.

Derrida, Jacques. Margins of Philosophy. Chicago: University of Chicago, 1982.

Derrida, Jacques. Specters of Marx: The State of the Debt, the Work of Mourning, and the New International. New York: Routledge, 1994.

Derrida, Jacques. Speech and Phenomena: And Other Essays on Husserl's Theory of Signs. Evanston: Northwestern University, 1973.

Descallar, R. "Anarchism and Legal Rules." Law and Anarchism. Ed. Thom Holterman and Henc Van Maarseveen. Montreal: Black Rose, 1984. 190-215.

Fanon, Frantz. The Wretched of the Earth. New York: Grove, 1963.

Fernandez, Luis A. Policing Dissent: Social Control and the Anti-globalization Movement. New York: Rutgers University, 2008.

Foucault, Michel. The Essential Works of Foucault 1954-1984: Vol. 1: Ethics, Subjectivity, and Truth. Ed. Paul Rainbow. New York: New, 1997.

Foucault, Michel. "The Ethic of Care for the Self as a Practice of Freedom." The Final Foucault. Ed. James William. Bernauer and David M. Rasmussen. Cambridge, MA: MIT, 1988. 1-20.

Foucault, Michel. The History of Sexuality. New York: Vintage, 1980.

Foucault, Michel. "On the Genealogy of Ethics: An Overview of Work in Progress." Ed. Paul Rabinow. The Foucault Reader. New York: Pantheon, 1984. 340-72.

Foucault, Michel. Security, Territory, Population: Lectures at the Collège De France 1977-1978. Basingstoke: Palgrave Macmillan, 2007.

Foucault, Michel. "Society Must Be Defended": Lectures at the Collége De France, $1975-$ 76. New York: Picador, 2003. 
Foucault, Michel. "The Subject and Power." Critical Inquiry 8.4 (1982): 777-95.

Franks, Benjamin. "The Direct Action Ethic." Anarchist Studies 11.1 (2003): 13-41.

Franks, Benjamin. "Postanarchism: A Critical Assessment." Journal of Political Ideologies 12.2 (2007): 127-45.

Gautney, Heather. Protest and Organization in the Alternative Globalization Era: NGOs, Social Movements, and Political Parties. Basingstoke: Palgrave Macmillan, 2012.

Glendinning, Simon. "Politics and Justice." Derrida: A Very Short Introduction. Oxford: Oxford University, 2011. 78-98.

Gordon, Uri. Anarchy Alive!: Anti-authoritarian Politics from Practice to Theory. London: Pluto, 2008.

Graeber, David. Direct Action: An Ethnography. Edinburgh: AK, 2009.

Graeber, David. Fragments of an Anarchist Anthropology. Chicago: Prickly Paradigm, 2004.

Graeber, David. "The New Anarchists." New Left Review 62.13 (2002): 61-73.

Hobbes, Thomas. Leviathan. Ed. Richard Tuck. Cambridge: Cambridge University, 1991.

Hodgson, Torrance. "Post-Anarchism and Social War: Post-Structuralism, and the Revival of an Anarchist Subterranean." Thesis. Victoria University of Wellington, New Zealand, 2007.

Invisible Committee, The. The Coming Insurrection. Los Angeles, CA: Semiotext(e), 2009.

Juris, Jeffrey S. Networking Futures: The Movements Against Corporate Globalization. Durham, NC: Duke University, 2008.

Kropotkin, Peter. The Conquest of Bread. Montréal: Black Rose, 1990. 
Kropotkin, Peter. Revolutionary Pamphlets: A Collection of Writings. Ed. Roger

Baldwin. New York: Blom, 1968.

Maeckelbergh, Marianne. The Will of the Many: How the Alterglobalisation Movement Is Changing the Face of Democracy. London: Pluto, 2009.

Marshall, Peter. Demanding the Impossible: A History of Anarchism. London: Harper Collins, 1992.

Marx, Karl, and Friedrich Engels. The Marx-Engels Reader. Ed. Robert C. Tucker. New York: Norton, 1978.

May, Todd. "Anarchism from Foucault to Rancière." Contemporary Anarchist Studies: An Introductory Anthology of Anarchy in the Academy. Ed. Randall Amster, Abraham Deleon, and Luis A. Fernandez. Abingdon, Oxon: Routledge, 2009. I117.

May, Todd. The Political Philosophy of Poststructuralist Anarchism. University Park, PA: Pennsylvania State University, 1994.

McKay, lain. An Anarchist FAQ. Oakland, CA: AK Press, 2008.

McLaren, Margaret A. Feminism, Foucaul, and Embodied Subjectivity. Albany, NY: State University of New York, 2002.

Newman, Saul. From Bakunin to Lacan: Anti-authoritarianism and the Dislocation of Power. Lanham, MD: Lexington Books, 2001.

Newman, Saul. The Politics of Postanarchism. Edinburgh: Edinburgh University, 2010.

Newman, Saul. Power and Politics in Poststructuralist Thought: New Theories of the Political. London: Routledge, 2005.

Newman, Saul. Unstable Universalities: Poststructuralism and Radical Politics. 
Manchester: Manchester University, 2007.

Pyziur, Eugene. The Doctrine of Anarchism of Michael A. Bakunin. Milwaukee: Marquette University, 1968.

Shantz, Jeff. Active Anarchy: Political Practice in Contemporary Movements. Lanham, MD: Lexington Books, 2011.

Starhawk. Webs of Power: Notes from the Global Uprising. Gabriola Island, BC: New Society, 2002.

Thompson, A. K. Black Bloc, White Riot: Anti-globalization and the Genealogy of Dissent. Oakland, CA: AK Press, 2010.

Tiqqun. The Theory of Bloom. Portland, OR: LBC, 2012. Found online at The Anarchist Library. <http://theanarchistlibrary.org/library/tiqqun-bloom-theory>.

Tiqqun. This Is Not a Program. Los Angeles, CA: Semiotext(e), 2011.

The Toronto Community Mobilization Network. Web. <http://g20.torontomobilize.org>. Trapese Collective. Do It Yourself: A Handbook for Changing Our World. London: Pluto, 2007.

Trocchi, Alex. "For the Insurrection to Succeed, We Must First Destroy Ourselves." Revolt and Crisis in Greece: Berween a Present Yet to Pass and a Future Still to Come. Ed. Antonis Vradis and Dimitris Dalakoglou. Oakland, CA: AK Press, $2011.299-328$.

Ward, Colin. Anarchy In Action. London: Freedom Press, 1982.

Williams, Leonard, and Brad Thomson. "The Allure of Insurrection." Anarchist Developments in Cultural Studies. Ten Years After 9/11: An Anarchist Evaluation $1(2011): 265-89$ 